\title{
Made for This Moment: The Enduring Relevance of Adolf Berle's Belief in a Global New Deal
}

\author{
Leo E. Strine, $J r^{*}$
}

\begin{abstract}
At a time when the insecurity of working people in the United States and Europe is being exploited by nativist forces, the concept of a global New Deal is more relevant than ever. But, instead of a global New Deal, the predominant force in international trade in recent decades has been spreading pre-New Deal, laissez-faire approaches to markets, without extending with equal vigor the regulations essential to providing ordinary people economic security. Adolf Berle recognized that if the economy did not work for all, the worst impulses in humanity could be exploited by demagogues and authoritarians, having seen this first hand in the 1930s. Berle believed in international trade and economic dynamism. But he understood that growth in each produces instability, the potential for lost jobs, and human insecurity that governments, preferably working in concert, have the duty and capacity to address. That is why he advocated for a global New Deal that would extend the key elements necessary to a fair economy to cover the full scope of the transnational economy.

This Article identifies support in Berle's writing for addressing economic inequality and insecurity and ensuring that the advances for working people accomplished by the New Deal and social democracy in the OECD nations are preserved and extended to working people in developing nations. Because Berle was both a believer in facts and an optimist, one senses that he would now be arguing for a muscular and bold international agenda to increase the security of working people in the developed world while simultaneously strengthening trade and opportunities for people in the developing world.
\end{abstract}

* Chief Justice, Delaware Supreme Court; Adjunct Professor of Law, University of Pennsylvania Law School; Austin Wakeman Scott Lecturer in Law, Harvard Law School; Senior Fellow, Harvard Program on Corporate Governance; and Henry Crown Fellow, Aspen Institute. The author is grateful to Christine Balaguer, Kayla DeLeon, Peggy Pfeiffer, and Monica Smith for their help, and to Martin Lipton, Miguel Padro, Frank Partnoy, and Robert Thompson for their incisive comments. 
Berle's writings indicate that working people would be central to his focus, and signal his support for stronger minimum wages appropriate to the conditions of different tiers of the world economy, guarantees for workers to bargain for higher wages, and protections against child labor, unfair hours, and unsafe working conditions. Berle also advocated for other policies that have current relevance, such as investments in infrastructure, evolving technology, environmental protection, and education to create employment opportunities, improve quality of life, and make the United States more competitive. Berle's work also indicates that he would view the U.S. as well positioned to pay for needed action by asking the wealthy winners to pay their fair share and by enacting Pigouvian taxes that would also reduce the risks of financial speculation and carbon use. This Article outlines key components that could form the basis for Berlean transnational understandings to create more economic security for working people and thus continue globalizing trade while addressing the legitimate concerns of workers in the OECD nations.

I.

In this Article, I discuss why Adolf Berle-who I call the good Adolf - would not be surprised by the moment in which the United States, Great Britain, and the European Union now find themselves. And most important, I will underscore why Berle's support for a global New Deal remains relevant, and even compelling.

Many now tagged with the label "globalist" have spent nearly two generations globalizing a form of economics that Berle himself would have seen as outdated, socially unsustainable, and likely to give rise to resentment. ${ }^{1}$ One example of globalists of this kind include recently resigned presidential economic advisor, Gary Cohn. Cohn resigned over tariffs. ${ }^{2}$ But Cohn's kind of commitment to spreading laissez-faire economic policies is not characteristic of the sort of internationalist Berle was, nor Franklin Delano Roosevelt or Winston Churchill. On the left, the term globalization is often viewed unfavorably, as the word for spreading

1. Stanley Hoffmann, Clash of Globalizations, ForeIGN AfF., July-Aug. 2002, at 107 ("[E]conomic globalization... results from recent revolutions in technology, information, trade, foreign investment, and international business. The main actors are companies, investors, banks, and private services industries, as well as states and international organizations.").

2. Shawn Tully, Why Gary Cohn Was Right About Tariffs, FORTUNE (Mar. 7, 2018), http:// fortune.com/2018/03/07/gary-cohn-leaving-tariffs/ [https://perma.cc/97LR-4BEE] ("Cohn lost a battle with the 'nationalist' wing at the White House led by Peter Navarro, President Trump's top adviser on trade. As the president's chief economic adviser, Cohn has proven an ardent free-trader who strongly opposed Trump's plan to impose heavy tariffs on steel and aluminum imports. When Trump took his biggest concrete steps yet to deliver on his protectionist campaign promises, Cohn apparently quit in protest.”). 
laissez-faire capitalism, eroding social democracy, and advancing powerful business interests over those of working people. ${ }^{3}$ Instead of spreading a global New Deal, which Berle ardently supported, the predominant force in international trade has been to spread pre-New Deal, laissez-faire approaches to markets, without at the same time extending with equal vigor the important features of regulation, such as worker protections. Berle (and those he influenced, notably FDR) considered these features essential to providing ordinary people the economic security that they deserve, without which social stability could not endure. ${ }^{4}$

Berle's writing anticipated the present moment. He long recognized that if the economy did not work for all, the worst impulses in humanity would be ripe for exploitation by demagogues and authoritarians. Berle believed in international trade and economic dynamism. But he

3. See generally Gordon Laxer, Radical Transformative Nationalisms Confront the US Empire, 51 CURRENT SOC. 133, 139 (2003) (discussing the association of the term globalization with the spread of capitalism worldwide and even with recolonization, and urging that national policies and a movement for internationalism emerge to reverse what the author sees as the inequality and environmental harm flowing from globalizing capitalism); Gordon Laxer, The Movement that Dare Not Speak Its Name: The Return of Left Nationalism/Internationalism, 26 ALTERNATIVES 1 (2001) (discussing the Left's frustration with "neo-globalists" who wish to globalize capitalism and erode social democracy, and the fracturing it has caused on the Left about the utility of internationalism versus retreating behind borders to address the resulting problems of globalizing capitalism without correspondingly expanding regulation and protections for working people); Amy Skonieczny, Interrupting Inevitability: Globalization and Resistance, 35 ALTERNATIVES 1 (2010) (discussing strategies for preventing the success of neo-globalists in advancing their agenda); A.K. Thompson, Bringing the War Home: Anti-Globalization and the Search for "The Local," 51 BERKELEY J. SOC. 183 (2007) (advocating strategies for white middle-class activists to undertake at the local level as a counterweight to neo-globalism); Roland Bleiker, The Politics of Change: Why Global Democracy Needs Dissent, 9 GEO. J. INT'L AFF. 33 (2008) (arguing that dissent against neo-globalization is important to building toward a fair form of internationalism focused on global democracy and human rights).

4. William K. TABb, ECONOMic Governance IN the AgE OF Globalization 91 (2004) (“In the post-postwar years, globalization gained momentum as transnational corporations outgrew national boundaries and the postwar strategies of promoting national champions proved a poor one in the face of the greater efficiency of the transnational corporation."); id. at 92-93 ("Globalization reawakens the free market utopian dream of an unregulated economy. But once again income polarization, social disintegration, and failed states unable to cope with anarchy of the global marketplace call out for new regulation, a new phase in the double movement - this time to address the neoclassical globalist utopian project. Corporate globalization's logic is supported by the formulation of free trade classical liberals who believe considerations such as labor rights and environmental protection should remain at the GSEGI [Global State Economic Governance Institution] policy level unrelated to trade and investment. Social protection is declared protectionism, redistributive justice rent seeking, environmental concerns anti-business, and democratic participation economically inefficient and in need of being precluded by international agreements. The conflict between unfettered capitalism and social democracy is once again sharp, even if unacknowledged in most mainstream discussion which frames the issues. Neoclassical versions of the story deny the state role in the establishment of corporate globalization. It pictures the creation of the capitalist market society as a free choice entered into for mutual advantage and whose historical evolution is theorized to be the result of individual efficiency enhancing activities."). 
understood that growth in each produced instability, the potential for lost jobs, and genuine human insecurity that governments, preferably working in concert, had the duty and capacity to address.

Davos Democrats and Brussels Social Democrats-"Davos Democrats" for short ${ }^{5}$ - talk a high-minded game after getting off chartered flights to conferences populated by the wealthy. Berle would not be surprised that they would lose working class support, having failed to address the growing economic insecurity and inequality in the American and EU economies. Occupying the odd position of being on the political left at home and thus in the part of the political spectrum most representative of the working and lower-middle classes, while being an important force behind globalizing pre-New Deal capitalism abroad, center-left political elites found themselves vulnerable to arguments that they were out of touch with the concerns of ordinary people and focused on, for want of a better term, their own "high class" problems.

Even less would Berle be surprised that unsavory, nativist forces would take advantage of the insecurity of working people feeling that they were going backward, while a small, privileged elite was growing even wealthier. Having lived through the 1930s, Berle would be all too familiar with the elites blaming the struggles of ordinary people on foreign powers, immigrant workers, and open markets. That these forces would be strengthened during the recovery from the Great Recession, which left the best off with even more of the wealth, and the middle and working classes struggling to get back to where they were, is something he would have expected.

Most of all, Berle would have feared that these forces would emerge triumphant if there was not a forceful plan for action to address the profound insecurity of the working and middle classes. To the extent that Berle ever criticized FDR, it was because the New Deal did not go far enough. ${ }^{6}$ Berle did not believe in retreating behind national borders. $\mathrm{He}$

5. See generally Matthew Yglesias, Paul Krugman Says Davos Democrats Are Over, and the Leading Davos Democrat Agrees, Vox (June 15, 2015), https://www.vox.com/2015/6/15/8783655/ davos-democrats [https://perma.cc/GFV3-6QWD] (explaining the term as "a reference to an annual gathering of global financial and political elites in Davos, Switzerland that's come to serve as a standin for a certain brand of centrist, business-friendly internationalism").

6. Berle revered FDR, and although known for his own intellectual self-confidence, resolutely defended FDR's keen intelligence, careful study, and grasp of the key policies central to the New Deal. Interview by James E. Sargent with Adolf A. Berle, Jr., in N.Y.C. (June 18, 1969), at 20-22 [hereinafter 1969 Interview with Berle]; Adolf A. Berle, Jr., Reshaping the American Economy, 9 CEnTENnial Rev. 209, 218 (1965) [hereinafter Reshaping the American Economy] ("Looking back, it is clear that (despite contrary accusations) the President was over-cautious rather than over-bold in his public works and allied programs. Had he, for example, financed the reconstruction of cities in 1933 and 1934, as his government financed creation of an army, navy, and air force and supporting services of supply from 1939 on, the problem might have been wholly, instead of partially, met through peacetime instead of wartime employment."). 
believed in internationalism, but in an internationalism that was robust and that involved globalizing the protections for workers and the vulnerable that he viewed as critical to making capitalism work for the many. ${ }^{7}$ Rather than a government that left those unsettled by a rapidly changing economy to fend for themselves, Berle believed that government had both the duty and capacity to help them find new work and to be secure. ${ }^{8}$

Berle would have grated to see the kernels of a positive message like "Make America Great Again" deployed in aid of a nativist message premised on trade wars and retrenchment. During his lifetime, Berle called on the United States to build a more fair, more prosperous, and more just society. He viewed us as having an immense capacity to invest our collective wealth in improving our society's infrastructure and cultural and educational institutions; he viewed those investments not just as complementary to economic growth, but essential to it. ${ }^{9}$ And perhaps most relevant of all, Berle did not view American progress as a unique exercise in social democracy to be done in isolation from our international neighbors. ${ }^{10}$ To the contrary, Berle viewed it as vital that the United States promote what he called "free democracy" internationally and that the enlightened form of capitalism associated with the New Deal be expanded to cover the scope over which a globalizing economy operated. ${ }^{11} \mathrm{He}$

7. See generally Adolf A. Berle, Jr., Government Function in a Stabilized National Economy, 33 Am. ECON. Rev. 27 (1943) [hereinafter Government Function]; Adolf A. Berle, Jr., Private Property in a Socialist World, 1946 A.B.A. Sec. Real Prop. Prob. \& TR. Proc. 48 [hereinafter Private Property]; Adolf A. Berle, Jr., A Cooperative Union of Free Nations: Welfare of the Masses the Primary Objective, 27 VITAL SPEECHES OF THE DAY 467 (1961) [hereinafter Welfare of the Masses]; Adolf A. Berle, Jr., The Quest for Individual Security, 17 ViTAL SPEECHES OF THE DAY 406 (1951) [hereinafter The Quest for Individual Security].

8. Reshaping the American Economy, supra note 6.

9. See generally Adolf A. Berle, Jr., Reflections on Financing Governmental Functions of the Metropolis, 27 ACAD. POL. SCI. PROC. 66 (1960) [hereinafter Reflections on Financing Governmental Functions of the Metropolis]; Adolf A. Berle, Property, Production and Revolution, 65 Colum. L. REv. 1 (1965) [hereinafter Property, Production and Revolution]; Adolf A. Berle, Jr., Constitutional Limitations on Corporate Activity - Protection of Personal Rights from Invasion Through Economic Power, 100 U. PA. L. REV. 933 (1952) [hereinafter Constitutional Limitations on Corporate Activity]; Reshaping the American Economy, supra note 6; Adolf A. Berle, Jr., And What Shall We Do Then?, FORTUNE, Oct. 1941, at 102 [hereinafter And What Shall We Do Then?].

10. See, e.g., Adolf A. Berle, Jr., The Coming Epoch of Rebuilding, 4 DEP’T ST. BuLL. 611, 613 (1941) [hereinafter The Coming Epoch] ("[N]o nation exists by its own strength. If it lives at all, it can do so only because it is part of an international fabric ... . But if the single-unit nation cannot make war alone, neither can it make peace alone. To live at all it must draw supplies from every part of the world and must send back its own products. The foundation of national life is thus international; and every laborer, factory manager, businessman, and statesman knows that this is true."); Adolf A. Berle, Jr., Cooperative Peace in the Western Hemisphere, 1 DEP'T ST. Bull. 659, 661 (1939) ("It has long been recognized that economic forces are not strictly national, just as it has long been recognized by all serious students that unless trade relationships are unobstructed, the prosperity of any nation is limited, if not imperiled.").

11. Adolf A. Berle, JR., Natural Selection of Political Forces 99 (1950) [hereinafter Natural Selection of Political ForCes]; see also Adolf A. Berle, Jr., Basic Elements in the New 
argued for the expansion and strengthening of international institutions that would guarantee all humans the fundamental rights - all of themcalled for by FDR's Four Freedoms Speech. ${ }^{12}$

Because Berle was a realist, a believer in facts, and an optimist, one senses that he would now be arguing for a muscular and bold international agenda to increase the security of working people in the developed world while simultaneously strengthening trade and opportunities for people in the developing world. ${ }^{13}$ From Berle's writings, it seems likely that the rights and needs of working people would be central to his focus. At the top of his agenda would likely be support for stronger minimum wages appropriate to the conditions of different tiers of the world economy, guarantees for workers to bargain for higher wages, and protections against child labor, unfair hours, and unsafe working conditions. ${ }^{14}$ So

World Crisis, 27 AM. Scholar 423 (1958) [hereinafter Basic Elements]. Berle's full-throated denunciation of President Wilson's failure (for among other reasons, his unwillingness to support requirements for racial equality) to adhere to a principled plan for a post-World War I disarmament and a League of Nations illustrates his view that the U.S. had a duty to support an international system that worked for all nations, not just itself. Adolf A. Berle, Jr., The Betrayal at Paris, 109 NATION 170 (1919); see also Adolf A. Berle, Jr., Our Undeclared War, 23 New RePUBLIC 92 (1920).

12. Franklin D. Roosevelt, Annual Message to Congress: State of the Union Address (Jan. 6, 1941), http://www.presidency.ucsb.edu/ws/index.php?pid=16092 [https://perma.cc/8C2V-ANZE] [hereinafter Four Freedoms Speech] ("In the future days which we seek to make secure, we look forward to a world founded upon four essential human freedoms. The first is freedom of speech and expression-everywhere in the world. The second is freedom of every person to worship God in his own way - everywhere in the world. The third is freedom from want - which, translated into world terms, means economic understandings which will secure to every nation a healthy peacetime life for its inhabitants - everywhere in the world. The fourth is freedom from fear-which, translated into world terms, means a world-wide reduction of armaments to such a point and in such a thorough fashion that no nation will be in a position to commit an act of physical aggression against any neighbor-anywhere in the world."). See generally Basic Elements, supra note 11; Adolf A. Berle, Jr., The Soviet-Chinese Complex, 294 AnNALS AM. ACAD. POL. \& SOC. SCI. 56 (1954) [hereinafter The Soviet-Chinese Complex].

13. See generally Basic Elements, supra note 11; Adolf A. Berle, Jr., Expansion and Values, 17 AM. SCHOLAR 231 (1948) [hereinafter Expansion and Values]; The Soviet-Chinese Complex, supra note 12; Adolf A. Berle, Jr., Peace Without Empire, 30 SuRV. GRAPHIC 506 (1942) [hereinafter Peace Without Empire].

14. For example, in 1941, before the U.S. had even formally entered WWII, Berle was already anticipating the post-war economy with characteristic optimism and confidence:

There is no need for fear. Rather, we shall have an opportunity to create the most brilliant economic epoch the U.S. has yet seen. It is entirely feasible to make the country at once more prosperous and more free than it has ever been. We shall have in our hands the tools by which we can create a greater measure of economic justice, without sacrificing any of the essential freedoms.

And What Shall We Do Then?, supra note 9, at 102 (emphasis added). See generally Reshaping the American Economy, supra note 6, at 219 ("[I]t is hard even to imagine the possibility of having an economy ... without minimum wage laws and social security."); Welfare of the Masses, supra note 7, at 469 (arguing that "assur[ing] that increased production shall benefit everyone is a social task" that requires "the right of free labor to secure for workmen a fair share through wages and social insurance"); The Quest for Individual Security, supra note 7, at 407 (arguing that social security should "be gradually extended on a modest scale until substantially everyone who really wishes to work will 
fairer trade would ensue, workers everywhere would have more leverage to gain higher wages, and pressures to offshore jobs solely to exploit cheap and unfairly treated labor would diminish. Always clear-eyed about the costs of economic dynamism, Berle voiced in his lifetime the still relevant concern that government has a duty to help employees transition to new forms of employment. ${ }^{15}$ And Berle recognized that one way that government could facilitate economic growth and opportunity was by marshaling society's production capacity to build and improve needed infrastructure. ${ }^{16}$ Thus, Berle would have grasped the obvious opportunity for the United States and its Organisation for Economic Co-operation and Development (OECD) allies to revitalize its core infrastructure, and thereby create good jobs at home, train workers in new skills, and meet the challenges presented by climate change. Finally, Berle understood that the privileged few should be expected to pay taxes to cover the costs of running a society in a fair and balanced manner. ${ }^{17} \mathrm{He}$ would view the United States as well positioned to pay for needed action, simply by asking the wealthy winners to pay their fair share and by enacting Pigouvian taxes that reduce the risks of financial speculation and the use of carbon.

In this Article, I will give you solid examples of why I see Berle's thinking as relevant to the current moment. I will start by highlighting Berle's sharp focus on economic security for ordinary people, lest society become unfair and the worst elements of human nature be subject to exploitation by authoritarian demagogues. Next, I will underscore Berle's belief that government has the duty and capacity to manage the economy in a way that spreads the blessings of capitalism fairly. ${ }^{18} \mathrm{I}$ will then discuss Berle's support for a global New Deal and the expansion of international

be covered by the government minimum," and that there should be a "modest, universally applicable pension for old age, and a modest cushion for unemployment"); Government Function, supra note 7, at 27 (calling for "an attempt to assure substantially general opportunity for useful work at adequate pay"); Adolf A. Berle, Jr., The Duties and Obligations of American Citizenship, 10 DEP'T ST. BulL. 281 (1944) ("The day of the exploiter is gone, and exploitation can be no part of American policy. The success of an American enterprise outside the United States will be measured even more by the working-conditions it creates, by the health and homes of its employees, and by the growing capacity of the people with which it works, than by the mere size of its profit-account piling up in banks in New York or Chicago.").

15. See generally Government Function, supra note 7; And What Shall We Do Then?, supra note 9.

16. See generally id.; Reflections on Financing Governmental Functions of the Metropolis, supra note 9; Reshaping the American Economy, supra note 6; And What Shall We Do Then?, supra note 9.

17. See generally Property, Production and Revolution, supra note 9; Adolf A. Berle, Penrose Memorial Lecture: The Laws of Power: An Approach to Its Systematic Study, 11 AM. PHIL. Soc'Y PROC. 249 (1967).

18. See generally Adolf A. Berle, Jr., The Modern Corporation in the Modern State, 8 Bus. LAW. 3 (1952); Adolf A. Berle, Jr., Concentration of Economic Power and Protection of Freedom of Expression, 300 AnNals AM. ACAD. POL. \& SOC. SCI. 20 (1955). 
institutions that would extend the enlightened form of capitalism, the New Deal, and European social democracy exemplified to all parts of the globe connected to international trade. In doing so, I will note Berle's view that retrenchment beyond national boundaries, although having a potent political appeal, was not an answer to the anxiety raised by a globalizing economy. Instead he believed that the answer was making sure that as the scope of the effective economy expanded across national lines, so did the protections needed to address the economic security of working people. ${ }^{19}$ Finally, I will identify in Berle's writing, support for many of the initiatives that are now relevant to increasing support among working people for international trade and to ensuring that the advances for working people accomplished by the New Deal and social democracy are preserved and extended to working people in developing nations. Berle's focus on universally applicable principles is especially important to the present moment, ${ }^{20}$ where there is a natural inclination to focus solely on the local, given the difficulty of national, much less, international action. By focusing on local and national solutions that, with appropriate adaptation, can be applied universally across the global economy, those committed to the kind of fair economy that Berle desired can make progress and increase the international ties that are necessary if a global New Deal is ever to become a reality.

II.

The present moment echoes the period in which Berle became an influential government advisor. In the early 1930s, the American and European economies were struggling with the Great Depression. As a result of great economic change, there was growing economic inequality in the United States, even before the Crash. ${ }^{21}$ A class of the super wealthy and very affluent had emerged in the "Roaring 20s," while working people were still struggling to obtain rights we now think of as standard, such as protections against child labor, excessive hours, and unsafe working conditions. ${ }^{22}$ Things like the minimum wage did not exist as national

19. See generally Basic Elements, supra note 11.

20. See generally NATURAL SELECTION OF POLITICAL ForCES, supra note 11.

21. Jack LaWrence Luzkow, The Great Forgetting: The Past, Present and Future of Social Democracy AND THE Welfare State 143 (2015) (noting that in the 1920s, "the concentration of wealth in the hands of few achieved excessive levels, producing almost unprecedented social inequality").

22. We take these things for granted now. But, mainstream business voices viewed them as radical and dangerous. See, e.g., Press Comment on Wages and Hours Bill, N.Y. TIMES, June 14, 1938, at 4 (Alfred P. Sloan, Jr., Chairman of General Motors, predicting "that enactment of the [Wages and Hours Bill] will lead to further unemployment and will penalize the very group that it is supposed to help"). 
policy, and the right of workers to unionize was still not protected by law. ${ }^{23}$ After the Crash, genuine poverty and high unemployment ensued, leading to demands for action. ${ }^{24}$

When these conditions were then compounded by the Depression, they were exploited by forces in the U.S. and abroad that were not as benign as FDR, Frances Perkins, and Lord Maynard Keynes. Right wing fascists of various degrees of evil used these conditions to rally nativist sentiment against elites in the world economy, ${ }^{25}$ most particularly targeting successful Jews, and to urge nationalist and authoritarian

23. Franklin D. Roosevelt, Fireside Chat (June 24, 1938), https://www.presidency.ucsb.edu/ node/208978 [https://perma.cc/HGB9-VYV3] ("After many requests on my part the Congress passed a Fair Labor Standards Act, commonly called the Wages and Hours Bill. That Act-applying to products in interstate commerce - ends child labor, sets a floor below wages and a ceiling over hours of labor. Except perhaps for the Social Security Act, it is the most far-reaching, far-sighted program for the benefit of workers ever adopted here or in any other country. Without question it starts us toward a better standard of living and increases purchasing power to buy the products of farm and factory.").

24. Government Function, supra note 7, at 28-29 ("In 1929, when a new depression, likewise beyond the control of any individual or group of individuals or any set of private enterprises, resulted in the dislocation of a group of workers loosely estimated at eleven million, to which must be added the distress of farming communities aggregating not less than four or five million more active workers, the then government attempted to deal with the situation without direct entry into the field. Local governments, of course, were forced into the task of relief, and a number of them in one way or another attempted direct re-employment; and the government itself attempted provision through programs of 'share the work' and through indirect programs of encouraging large business to undertake programs of expansion offering the hope of re-employment. These measures proved insufficient and the political and governmental pressures resulting made it inevitable that there should be a major change in the situation. In result, in 1933 the federal government assumed responsibility and undertook the task of gradually providing for the economic welfare of substantially every American. Failure to do so would, in my judgment, inevitably have resulted in even greater political pressure. In retrospect, it is sufficiently plain that this pressure would have been applied quite irrespective of the party affiliations or ideology of the administration."); 1969 Interview with Berle, supra note 6, at 9 (discussing the Crash and noting that "the American public was not at all in a revolutionary mood. They didn't want to overthrow the government, they wanted to go to work. They didn't want to abolish private property, they just wished they had some for themselves.").

25. See generally Lorraine Boissoneault, The True Story of the Reichstag Fire and the Nazi Rise to Power, SMithsonian (Feb. 21, 2017), https://www.smithsonianmag.com/history/true-storyreichstag-fire-and-nazis-rise-power-180962240/ [https://perma.cc/74VK-T2DR] ("Despite its considerable growth, the Nazi party won only 2.6 percent of the vote in the 1928 election. But then the Great Depression hit, sending the U.S. and Europe into an economic tailspin and shooting the number of unemployed up to 6 million people in Germany (around 30 percent of the population). The sudden slump caused massive social upheaval, which the Nazis exploited to gain further political traction. By 1930, the Nazis won 18.3 percent of the Reichstag vote and became the second largest party after the Social Democrats, while the Communist party also grew to ten percent of the vote."); Caleb Crain, Is Capitalism a Threat to Democracy?, NEW YoRKER, May 14, 2018, at 92, https:// www.newyorker.com/magazine/2018/05/14/is-capitalism-a-threat-to-democracy [https://perma.cc/ 2XF7-CBS2] ("For the next few decades [following the Great Depression], the world's leading economies were tightly managed by their governments .... The memory of the financial chaos of the thirties, and of the fascism that it gave rise to, was still vivid, and the Soviet Union loomed as an alternative, should the Western democracies fail to treat their workers well."). 
solutions to the Depression. ${ }^{26}$ The U.S. was by no means immune from these forces, as we know, ${ }^{27}$ and it is one of the signal achievements of American history that FDR preserved both our market economy and democracy, while responding to the legitimate economic fears of working people.

Berle was one of the strongest voices urging FDR to address the link between economic insecurity and the potential for the darker elements of human nature to find political success. In 1965, he described his thinking at that time this way:

No doubt economic forces left to themselves would "eventually" establish a balance - but the human cost of the process in 1933 had become intolerable. Continued, the vast and spreading misery could even threaten the foundations of the American State. Millions do not lose their jobs, their homes, and the necessities of life and see their wives and children in hunger in sweet reasonableness. Also, the phenomenon had become irrational. Great surpluses of goods had built up on one side of an economic plate glass window. They were there - in warehouses or grain elevators - while masses of hungry men looked at them in growing despair. Means had to be found to connect the supply with the need. An economic system is, of

26. Government Function, supra note 7, at 33-34 ("Clear economic thinking in these situations should make it plain that the area of interest between private enterprise and government is vastly greater than any minor area of conflict. Certainly, when the impulsion is as great as that which will be on us after the present World War, a failure to meet the situation is far more likely to destroy alike private enterprise and the chance of individuals to enjoy free choice of life. With the relatively minor adjustments and readjustments which had to be made up to 1921, governments could weather a period of distress. Impulsions as great as those of the depression of 1929 forced a considerable change in theory. The hydraulic impact of the pressures which will exist after the World War, if they are not met by common action, may produce reactions so great as to force direct intervention in many if not all fields."); id. at 34 ("This was the experience of most governments in Europe following the first World War. It led directly to change not only of governments (which might be merely political) but also to a change of the economic theory on which governments were based, respectively in Italy, Germany, and many of the Balkan countries, and very considerably shifted the area of British governmental action. In most of these cases the violence of the result was due to an attempt by certain interests to resist the impulsion and the measures towards which the government was forced, instead of an endeavor to work out the situation by taking account of all of the elements and endeavoring to assign to them different spheres of action, or to effect a frank co-operation so that the impulsions might be accurately and definitely met.").

27. By way of example, think of Father Coughlin, a Canadian-born cleric and "new kind of evangelical populist," who criticized "America's failed economic system" in his radio broadcasts beginning in 1926. Michael Kazin, The Populist Persuasion: An American History 119 (1995). Although Coughlin "had vigorously backed Roosevelt as a true foe of 'the money changers,"” during FDR's 1932 campaign, by 1934, he no longer supported FDR or the New Deal: “According to Coughlin, the New Deal, the Soviets, and modern capitalism had one essential quality in common: the drive to centralize power in the hands of a privileged few - whether liberal bureaucrats, international bankers, or atheistic tyrants." Id. at 123. As World War II approached, Coughlin's message became more focused on anti-Semitism, a message that linked to his earlier association of Jews with the international elites who he argued were the source of economic troubles for Americans. Id. at 131-33. 
necessity, a man-made system; what men make, they can alter. If to keep the service of supply going, the gods of the free market had to be dethroned, dethroned they must be. ${ }^{28}$

My own first memorandum to him (May of 1932) was predicated on the theory that the millions of individuals and families in distress were probably the key to the situation; if we could make these families reasonably secure in current income, in such savings as they still had, in their jobs, and give them some confidence in the economic future, they would cease to be frightened hoarders of cash, would resume consumption, and would thereby reactivate manufacture and production, for, as I wrote: "Both as a matter of sound economics and decent humanity, an economic policy of the government ought to be adopted towards the restoration of individual safety," and I suggested a series of concrete measures. All connoted the entry of the federal government into fields it had, theretofore, considered outside its function. ${ }^{29}$

And "security" is in fact the right word, and one that has a natural relation to anxiety, as anxiety is what happens when people feel insecure about their fundamental ability to find a job and provide for themselves. From FDR's famous words that the only thing Americans had to fear was fear itself, ${ }^{30}$ to the enactment of a system of "social security" to take away the anxiety of being old and without food, to FDR's call for a global New Deal, ${ }^{31}$ the economic plans that Berle urged FDR to adopt were all premised on making sure that everyone shared in the blessings of a productive society, and that certain rights were recognized as essential to human dignity and a fair society. Or as Berle himself put it, "the desire for

28. Reshaping the American Economy, supra note 6, at 211.

29. Id. at 213 .

30. Franklin D. Roosevelt, Inaugural Address (Mar. 4, 1933), https:/fdrlibrary.org/documents/ 356632/390886/First+Inagural+Address+Curriculum+Hub+Documents.pdf/55c42890-6b80-4d34b68a-b4a30f2797d5 [https://perma.cc/3ZQE-CVXP ] ("This is preeminently the time to speak the truth, the whole truth, frankly and boldly. Nor need we shrink from honestly facing conditions in our country today. This great nation will endure as it has endured, will revive and will prosper. So first of all let me assert my firm belief that the only thing we have to fear is fear itself - nameless, unreasoning, unjustified terror which paralyzes needed efforts to covert retreat into advance. In every dark hour of our national life a leadership of frankness and vigor has met with that understanding and support of the people themselves which is essential to victory. I am convinced that you will again give that support to leadership in these critical days.").

31. See Daniel J. Whelan \& Jack Donnelly, The West, Economic and Social Rights, and the Global Human Rights Regime: Setting the Record Straight, 29 HuM. RTS. Q. 908, 924-27 (2007) (tracing the evolution of FDR's "Four Freedoms" to an "Economic Bill of Rights," domestic principles that "emerged from a synthesis of New Deal reform with an appreciation of the need to develop an account of liberal democracy that would respond to the threats from fascism and communism," and internationalized in the Universal Declaration of Rights) (quoting CASS R. SunSTEIN, THE SECOND Bill Of Rights: FDR's Unfinished Revolution AND Why We NeEd It More Than Ever 65 (2004)). 
individual security is a constant in world history. It has always been so; it will always be so." 32

FDR recognized that the two world wars had their origins, in no small part, in exploitation of the resentments that accompanied economic dislocations in a rapidly changing world economy. In light of this, FDR, with Berle's full support, believed it was essential to universalize the focus on economic security at the heart of the New Deal, and to make it the basis for a durable world order based on a commitment to increasing prosperity for the benefit of the many. FDR emphasized this in his Four Freedoms Speech, where he famously included:

[F]reedom from want - which, translated into world terms, means economic understandings which will secure to every nation a healthy peacetime life for its inhabitants - everywhere in the world. ${ }^{33}$

In the present moment, the Four Freedoms speech has a special resonance because it highlights the gap between what FDR, Berle, and others believed to be the goal, and what has happened since.

In that same speech in 1941, FDR linked the lack of economic security to the World War then-occurring and in which the U.S. was soon to be embroiled itself:

Certainly this is no time for any of us to stop thinking about the social and economic problems which are the root cause of the social revolution which is today a supreme factor in the world.

For there is nothing mysterious about the foundations of a healthy and strong democracy. The basic things expected by our people of their political and economic systems are simple. They are:

Equality of opportunity for youth and for others.

Jobs for those who can work.

Security for those who need it.

The ending of special privilege for the few.

The preservation of civil liberties for all.

The enjoyment of the fruits of scientific progress in a wider and constantly rising standard of living.

These are the simple, basic things that must never be lost sight of in the turmoil and unbelievable complexity of our modern world. The inner and abiding strength of our economic and political systems is dependent upon the degree to which they fulfill these expectations.

32. The Quest for Individual Security, supra note 7, at 406.

33. Four Freedoms Speech, supra note 12. 
Many subjects connected with our social economy call for immediate improvement.

As examples:

We should bring more citizens under the coverage of old-age pensions and unemployment insurance.

We should widen the opportunities for adequate medical care.

We should plan a better system by which persons deserving or needing gainful employment may obtain it.

I have called for personal sacrifice. And I am assured of the willingness of almost all Americans to respond to that call.

A part of the sacrifice means the payment of more money in taxes .... [T] he principle of tax payments in accordance with ability to pay should be constantly before our eyes to guide our legislation. ${ }^{34}$

FDR repeated the key themes of his Four Freedoms speech in his 1944 State of the Union Address:

In our day these economic truths have become accepted as selfevident. We have accepted, so to speak, a second Bill of Rights under which a new basis of security and prosperity can be established for all regardless of station, race, or creed.

Among these are:

The right to a useful and remunerative job in the industries or shops or farms or mines of the Nation;

The right to earn enough to provide adequate food and clothing and recreation;

The right of every farmer to raise and sell his products at a return which will give him and his family a decent living;

The right of every businessman, large and small, to trade in an atmosphere of freedom from unfair competition and domination by monopolies at home or abroad;

The right of every family to a decent home;

The right to adequate medical care and the opportunity to achieve and enjoy good health;

The right to adequate protection from the economic fears of old age, sickness, accident, and unemployment;

The right to a good education. 
All of these rights spell security. And after this war is won we must be prepared to move forward, in the implementation of these rights, to new goals of human happiness and well-being.

America's own rightful place in the world depends in large part upon how fully these and similar rights have been carried into practice for our citizens. For unless there is security here at home there cannot be lasting peace in the world. ${ }^{35}$

35. Franklin D. Roosevelt, Annual Message to Congress: State of the Union Address (Jan. 11, 1944), http://www.presidency.ucsb.edu/ws/index.php?pid=16518 [https://perma.cc/VT3Z-HP9N]. In this speech, FDR essentially called for a global New Deal. Id. ("The best interests of each nation, large and small, demand that all freedom-loving nations join together in a just and durable system of peace .... And an equally basic essential to peace — permanent peace — is a decent standard of living for all individual men and women and children in all nations."). FDR's 1944 State of the Union Address was influential to the Declaration of Human Rights. Compare id., with G.A. Res. 217 (III) A, Universal Declaration of Human Rights, art. 22 (Dec. 10, 1948) ("Everyone, as a member of society, has the right to social security and is entitled to realization, through national effort and international co-operation and in accordance with the organization and resources of each State, of the economic, social and cultural rights indispensable for his dignity and the free development of his personality."), and id. art. 23 (" 1 . Everyone has the right to work, to free choice of employment, to just and favourable conditions of work and to protection against unemployment. 2. Everyone, without any discrimination, has the right to equal pay for equal work. 3. Everyone who works has the right to just and favourable remuneration ensuring for himself and his family an existence worthy of human dignity, and supplemented, if necessary, by other means of social protection. 4. Everyone has the right to form and to join trade unions for the protection of his interests."), and id. art. 24 ("Everyone has the right to rest and leisure, including reasonable limitation of working hours and periodic holidays with pay."), and $i d$. art. 25 ("Everyone has the right to a standard of living adequate for the health and well-being of himself and of his family, including food, clothing, housing and medical care and necessary social services, and the right to security in the event of unemployment, sickness, disability, widowhood, old age or other lack of livelihood in circumstances beyond his control."), and id. art. 26 ("1. Everyone has the right to education. Education shall be free, at least in the elementary and fundamental stages. Elementary education shall be compulsory. Technical and professional education shall be made generally available and higher education shall be equally accessible to all on the basis of merit. 2 . Education shall be directed to the full development of the human personality and to the strengthening of respect for human rights and fundamental freedoms .... 3. Parents have a prior right to choose the kind of education that shall be given to their children.), and id. art 27 ("1. Everyone has the right freely to participate in the cultural life of the community, to enjoy the arts and to share in scientific advancement and its benefits. 2. Everyone has the right to the protection of the moral and material interests resulting from any scientific, literary or artistic production of which he is the author."), and $i d$. art. 28 ("Everyone is entitled to a social and international order in which the rights and freedoms set forth in this Declaration can be fully realized."); see also Cass R. Sunstein, Economic Security: A Human Right; Reclaiming Franklin Delano Roosevelt's Second Bill of Rights, AM. PROSPECT (Sept. 20, 2004), http://prospect.org/article/economic-security-human-right [https://perma.cc/C72X-NQLA] ("Roosevelt's speech has had a large international influence; the Second Bill of Rights should be seen as a leading American export. The Universal Declaration of Human Rights, written in the shadow of FDR and accepted by the UN General Assembly in 1948, explicitly includes social and economic guarantees."). FDR's speech has also influenced key governing documents of other nations. Cass R. Sunstein \& Randy E. Barnett, Constitutive Commitments and Roosevelt's Second Bill of Rights: A Dialogue, 53 DRAKE L. REV. 205, 210 (2005) (detailing the influence of FDR's Second Bill of Rights on the constitutions of other nations, including Finland, Spain, Ukraine, Romania, Syria, Bulgaria, Hungary, Russia, and Peru). 
After World War II, the nascent United Nations adopted language that recognized the centrality of economic security to its mission, focusing on the objective of obtaining full employment for workers in the course of expanding international trade. For example, the document creating the World Trade Organization (WTO) listed some of its goals as:

Recognizing that their relations in the field of trade and economic endeavour should be conducted with a view to raising standards of living, ensuring full employment and a large and steadily growing volume of real income and effective demand, and expanding the production of and trade in goods and services, while allowing for the optimal use of the world's resources in accordance with the objective of sustainable development, seeking both to protect and preserve the environment and to enhance the means for doing so in a manner consistent with their respective needs and concerns at different levels of economic development. ${ }^{36}$

In his speech famous for the phrase "Iron Curtain," FDR's wartime partner, Winston Churchill, recognized the importance of economic security to sustaining a peaceful world order. He pointed to economic insecurity among working people in the wake of the World War as reflecting the most "prevailing anxiety." 37

In the aftermath of World War II, the United States attempted, without success, to embed protection for labor rights within the charter of the International Trade Organization, which as proposed included the provision that:

The members recognize that unfair labor conditions, particularly in the production for export, create difficulties in international trade,

36. Marrakesh Agreement Establishing the World Trade Organization, Apr. 15, 1994, 1867 U.N.T.S. 154

37. Winston Churchill, The Sinews of Peace (Mar. 5, 1946), https://winstonchurchill.org/ resources/speeches/1946-1963-elder-statesman/the-sinews-of-peace/ [https:/perma.cc/AQ78-LUS7]. The full paragraph from which these words are derived bears citing, as it resonates of FDR:

I have now stated the two great dangers which menace the homes of the people: War and Tyranny. I have not yet spoken of poverty and privation which are in many cases "the prevailing anxiety." But if the dangers of war and tyranny are removed, there is no doubt that science and co-operation can bring in the next few years to the world, certainly in the next few decades newly taught in the sharpening school of war, an expansion of material well-being beyond anything that has yet occurred in human experience. Now, at this sad and breathless moment, we are plunged in the hunger and distress which are the aftermath of our stupendous struggle; but this will pass and may pass quickly, and there is no reason except human folly or sub-human crime which should deny to all the nations the inauguration and enjoyment of an age of plenty. I have often used words which I learned fifty years ago from a great Irish-American orator, a friend of mine, Mr. Bourke Cockran. "There is enough for all. The earth is a generous mother; she will provide in plentiful abundance food for all her children if they will but cultivate her soil in justice and in peace." 
and accordingly, each member shall take whatever action may be appropriate and feasible to eliminate such conditions within its territory. ${ }^{38}$

But that did not occur. Within the community of those who believed in international trade, factions emerged, and what largely won out was a commitment to expanding the world economy and providing clout behind global capital and product providers, while providing lip service to internationalizing protections for working people. ${ }^{39}$ Thus, the General Agreement on Tariffs and Trade (GATT), and the GATT's successor, the WTO,${ }^{40}$ contain no protections for workers' rights other than those against competition from prison labor. ${ }^{41}$ Moreover, the protections for workers

38. Drusilla K. Brown et al., International Labor Standards and Trade: A Theoretical Analysis, in FAir TRAdE AND HARMONIZATION: PREREQUisites For FreE TRADE? 5 (Jagdish N. Bhagwaiti \& Robert E. Hudec eds., 1996); see also Robert Kuttner, How the Globalists Ceded the Field to Donald Trump, AM. PRospeCt (Mar. 6, 2018), http://prospect.org/article/how-globalists-ceded-field-donaldtrump [https://perma.cc/MGD4-5U9N] ("The original International Trade Organization proposed at Bretton Woods called for a regime that would promote commerce but also defend enforceable labor standards. A treaty creating the ITO was negotiated in 1947, but never ratified.").

39. Kyle Bagwell \& Robert W. Staiger, The Simple Economics of Labor Standards and the GATT, in SOCIAL DimENSIONS OF U.S. TRADE POLICIES 195-96 (2000) ("GATT's approach to labor standards might be most aptly characterized as one of 'benign neglect' .... While there is an explicit provision within GATT articles that allows governments to restrict importation of the products of prison labor, the determination of domestic labor standards is for the most part considered the legitimate domain of each national government, and weak labor standards do not constitute a violation of GATT obligations .... Hence, for the most part, current GATT rules respect the sovereignty of domestic decisions over labor standards, as they allow each member government to determine its own labor policies without worrying about the ramifications of these choices for either its GATT obligations or those of its trading partners. It is the wisdom of preserving this national sovereignty over domestic labor policies while at the same time negotiating successive multilateral agreements to liberalize world trade which is now being challenged from various quarters in the United States and elsewhere in the industrialized world. The primary concern voiced by labor interests and social activists is that working conditions and wages in industrialized countries will suffer from trade liberalization as a result of increased import competition from countries where labor standards are weak or not enforced. It is feared that such pressures could fuel a 'race to the bottom,' in which the labor standards of the industrialized world are compromised in the name of international "competitiveness."').

40. World Trade Org., The Multilateral Trading System-Past, Present and FUTURE (May 14, 2018), https://www.wto.org/english/thewto_e/whatis_e/inbrief_e/inbr01_e.htm [https://perma.cc/8J7J-5ZDF] ("[T]he WTO is the successor to the General Agreement on Tariffs and Trade (GATT) established in the wake of the Second World War.").

41. Brown et al., supra note 38 ("Since the [GATT] was conceived with a more narrow mandate in mind, it did not address issues of labor standards, except in Article $\mathrm{XX}(\mathrm{e})$, which provides for prohibition of goods made with prison labor."); id. ("The United States continued to push for negotiation of a GATT article on labor standards in both the Tokyo and Uruguay rounds of multilateral trade negotiations. While receiving some support from other GATT member countries, the U.S. efforts continued to be unsuccessful."); Keith E. Maskus, Should Core Labor Standards Be Imposed Through International Trade Policy? 66 (World Bank Dev. Research Grp., Working Paper No. 1817, 1997), http://ctrc.sice.oas.org/geograph/labor/maskus.pdf ("[A]dvocates of strong international labor standards favor introducing a social clause into the WTO in some form."); id. at 59 ("Several times 
from the International Labor Organization (ILO) are limited to the merely admonitory. ${ }^{42}$

The failure of the U.S. to embed worker protections in GATT was not a pressing concern when the U.S. and EU were prospering in the postwar era. For a period lasting until the 1970s, other Western nations and their emerging allies enjoyed expanding prosperity and economic security, with strengthened social welfare states operating to address poverty, unemployment, and other economic needs for working people. ${ }^{43}$ The middle classes grew and economic inequality was reduced. ${ }^{44}$ To make a

during the evolution of the GATT, American trade authorities attempted to have language on fair labor standards introduced into the agreement, each time without success.").

42. OECD, InTERNATIONAL TRADE AND CORE LABOUR STANDARDS 4 (2000), https://www. oecd.org/tad/1917944.pdf [https://perma.cc/UC2L-YT83] ("In recent years, a broad international political consensus has emerged concerning the definition and recognition of a set of core labor standards .... At the same time, there is evidence of a continuing gap between the recognition and the application of core labour standards."); Maskus, supra note 41, at 67 ("If the WTO is not the appropriate international organization to address trade-related problems in labor standards, an important question is how the ILO could be strengthened in its monitoring and reporting of violations of [core labor standards]."); id. at 55 ("[T]he [ILO's] conventions have no binding powers of enforcement.... Indeed, the ILO has resisted the notion of international enforcement of its conventions on grounds that doing so could severely limit ratification and push many countries out of the organization altogether."); $i d$. at 57 ("The process by which the ILO operates is based on persuasion and peer pressure. ... National actions are monitored and governments are required to report on labor conditions and to justify their actions with respect to working conditions. ... The ILO studies these complaints and its findings are publicized, so that the offending, say, governmental restriction on bargaining rights or rights to strike becomes widely known. No other sanctions beyond public opinion exist.").

43. Crain, supra note 25, at 92 ("In the three decades following the Second World War ... [t] real income of Europeans rose as much as it had in the previous hundred and fifty years, and American unemployment, which had ranged between fourteen and twenty-five percent in the thirties, dropped to an average 4.6 percent in the fifties. The new wealth was widely shared, too; income inequality plummeted across the developed world."); John Gerard Ruggie, Globalization and The Embedded Liberalism Compromise: The End of an Era? 7 (MPIFG Working Paper No. 97/1, 1997) (“[T]he postwar international economic order rested on a grand domestic bargain: societies were asked to embrace the change and dislocation attending international liberalization, but the state promised to cushion those effects by means of its newly acquired domestic economic and social policy roles. Unlike the economic nationalism of the thirties, then, the postwar international economic order was designed to be multilateral in character. But unlike the laissez-faire liberalism of the gold standard and free trade, its multilateralism was predicated on the interventionist character of the modern capitalist state. Increasingly, this compromise is surpassed and enveloped externally by forces it cannot easily grasp, and it finds itself being hollowed out from the inside by political postures it was intended to replace.").

44. See Jordan Weissman, 60 Years of American Economic History, Told in 1 Graph, ATLANTIC (Aug. 23, 2012), https://www.theatlantic.com/business/archive/2012/08/60-years-of-americaneconomic-history-told-in-1-graph/261503/ [https://perma.cc/CH6J-M7JX] ("In the immediate postwar period, America's rapid growth favored the middle and lower classes. The poorest fifth of all households, in fact, fared best. Then, in the 1970s, amid two oil crises and awful inflation, things ground to a halt. The country backed off the postwar, center-left consensus - captured by Richard Nixon's comment that 'we're all Keynesians now'-and tried Reaganism instead. We cut taxes. Technology and competition from abroad started whittling away at blue collar jobs and pay. The financial markets took off. And so when growth returned, it favored the investment class - the top 20 
complex history simple, though, those halcyon days did not last. A globalizing economy disrupted things. Once global competition grew enormously starting in the 1970s, the lack of internationally enforceable protections of this kind meant that competitive pressures put downward pressures on social welfare spending and the leverage of working people in general; this left individual nations concerned that a strong welfare state might render them vulnerable to foreign competition from nations without similar policies or strong protections for workers.

Pressures to become more efficient to meet competition from nations with lower wages, as well as the lack of the kind of stronger social democratic protections for workers common in the Western nations, led the United States to downsizings, offshoring, and a substantial weakening of labor unions. ${ }^{45}$ Although the U.S. was quicker than the EU to respond in these ways, the trends there were in the same direction. Not only that, the post-war consensus in favor of the New Deal/Social Democratic managed economy frayed, and support for the pre-New Deal economics of laissez-faire grew. $^{46}$

percent, and especially the top 5 percent (and, though it's not on this chart, the top 1 percent more than anybody).”) (citing Pew Research Ctr., Fewer, Poorer, Gloomier: The Lost DeCAde of the MidDLE ClASS 9 (2012)), http://www.pewresearch.org/wp-content/uploads/sites/3/2012/08/pewsocial-trends-lost-decade-of-the-middle-class.pdf); Homi Kharas, The Unprecedented Expansion of the Global Middle Class: An Update 19 (Brookings Inst. Glob. Econ. \& Dev., Working Paper No. 100, 2017), https://www.brookings.edu/wp-content/uploads/2017/02/global_20170228_global-middl e-class.pdf [https://perma.cc/L4MF-6Q3A] ("In the heyday of middle-class growth in the U.S., Europe, and Japan, there was a close link between democratization and government support for the middle class. Government policy improved urban conditions, provided inner-city and intra-city transport, supported state-funded mass education for boys and girls, including at tertiary levels, and provided affordable housing and other social assistance programs such as health care and pensions. In other words, in today's advanced economies, the middle class developed because of public services as well as national economic growth .... Supporting the middle class became an essential component of democratic governance in advanced economies. In the U.S., New Deal programs such as the Works Progress Administration and the Social Security Act helped bring about an unprecedented rebound in the American middle class, adding 20 million people between 1932 and 1937.").

45. E.g., Karen C. Burke \& Grayson M.P. McCouch, Social Security Reform: Lessons from Private Pensions, 92 CORNELl L. REV. 297, 302 (2007) (observing "structural changes in [the] labor market[]" such as "intense competition from low-wage labor overseas, prompting employers to downsize workforces and demand significant concessions from the remaining employees").

46. As scholars have pointed out, even conservative supporters of free trade fear that a pure laissez-faire approach would erode support for opening markets. Ruggie, supra note 43, at 1-2 ("The editors of the [Financial Times] are conscious of the fact that the extraordinary success of postwar international economic liberalization hinged on a compact between state and society to mediate its deleterious domestic effects-what I have elsewhere termed the embedded liberalism compromise. They sensed that this compact is fraying throughout the western world. And they feared that if the compact unravels altogether, so too would public support for the liberal international economic order. In short, out of a firm commitment to free trade this stalwart of laissez-faire developed grave concerns about the growing inability or unwillingness of governments to perform the domestic policy roles they were assigned under the postwar compromise. Thus, thoughtful observers on both sides of the political 
Consequently, there has been a reluctance and lack of agreement to have the recognition and enforcement of widely shared conceptions of core labor standards ${ }^{47}$ be a condition to access to other markets under the WTO. ${ }^{48}$ Instead, many advocate for relegating workers to domestic legal protection, lest trade wars arise, concern for workers be used as a beard for purely protectionist impulses, and developing nations' workers suffer from an attempt to force their nations to embrace full-blown OECD-level protections before their nations are ready. ${ }^{49}$

As a result, Western workers faced more and more competition from companies making products in nations where workers did not have the same kinds of rights or protections, ${ }^{50}$ and companies had incentives to

aisle have begun to worry about the relationship between globalization and domestic economic insecurity.").

47. See, e.g., Council on Foreign Relations, Public Opinion on Global Issues: Chapter 6: WORLD OPINION ON THE GLOBAL ECONOMY 6, 34 (2009), https://www.cfr.org/backgrounder/ world-opinion-global-economy [https://perma.cc/6KZT-ENGV] (reporting the results of a poll of seventeen countries indicating that, on average, $81 \%$ of all respondents, $93 \%$ of respondents from the United States, and $95 \%$ of respondents from Great Britain think that parties to international trade agreements should be required to maintain minimum standards for working conditions).

48. OECD, supra note 42, at 2 ("At Singapore in December 1996, WTO members renewed their commitment to the observance of internationally recognized core labour standards," but they also "recognised that the ILO is the competent body to set and deal with core labour standards."); Maskus, supra note 41, at 58 ("It is fair to say that the ILO has grave concerns about the wisdom of writing a clause protecting minimum labor standards into the procedures of the World Trade Organization.").

49. See generally Drusilla K. Brown, Labor Standards: Where Do They Belong on the International Trade Agenda?, 15 J. ECON. PERSP. 89, 91 (2001) ("[C]ritics of international labor standards point out the unfairness of attempting to establish standards in all of these areas without regard for the level of economic development and cultural norms."); id. at 103 ("When countries remove tariffs and other barriers to trade in the context of international trade negotiations, they give up the policy tools normally used to turn the terms of trade to their advantage and to protect their import-competing producers. These protectionist urges are thus deflected onto domestic policies such as labor standards.”). But see DANI RoDRIK, STRAIGHT TALK ON TRADE 88 (2018) (“[T]here is no reason why workers in low income countries should be deprived of fundamental labor rights for the sake of industrial development and export performance. These include freedom of association and collective bargaining, reasonably safe working conditions, nondiscrimination, maximum hours, and restrictions on arbitrary dismissal. As with democracy, these are basic requirements of a decent society. Their first-order effect is to level the bargaining relationship between employers and employees, rather than to raise overall costs of production. And even when costs are affected, any adverse effects could be easily offset by improved morale, better incentives, and reduced turnover of the workforce.... [B]asic labor rights ... are not an impediment to economic development. They need not be postponed until economic takeoff takes place and is firmly entrenched.").

50. See generally AFL-CIO, ResPonsibility OutSOURCED: Social Audits, WorkPlace CERTIFicAtion AND Twenty Years of FAILURe to ProteCt WORKer Rights 9 (2014), https:// aflcio.org/sites/default/files/2017-03/CSReport.pdf [https://perma.cc/C8N3-AD7R] ("In the U.S. garment industry, sweatshop labor, dangerous conditions and poverty wages were greatly reduced from the 1930s through the 1970s mostly by holding major brands accountable for their subcontracting practices through the innovative binding collective bargaining arrangements known as jobbers agreements' that the U.S. government and both major political parties repeatedly supported .... Since at least the 1980s, major multinationals have become more globalized, building ever-longer, more flexible and complex globalized supply chains while avoiding whenever possible the limits placed on 
move production to places where labor was, well, just way cheaper. At the same time, organizations like the International Monetary Fund (IMF) and World Bank put intense pressure on developing nations to reduce their social welfare states and to adopt laissez-faire economics as their policy. ${ }^{51}$

Caught in this cross fire were parties of the center left, who wished to be open to trade, but whose working class members were among those most affected by the economic dislocations of globalization. Although the net benefits of globalization were real, so too were the negative effects for working people and the middle class. ${ }^{52}$

them by the state and unions. Since the 1990s, this only has accelerated. As manufacturing work has left countries in which there were laws, collective bargaining and other systems in place to reduce workplace dangers, jobs instead have gone to countries with inadequate laws, weak enforcement and precarious employment relationships with limited workers' voices to defend day-to-day worker interests or raise the alarm before disaster strikes. The improvements made in an earlier era in industrialized countries were achieved by unions, collective bargaining and state regulation. Yet workers, the supposed beneficiaries of these current CSR programs, rarely have much of a role in the CSR monitoring and certification system as it currently exists.").

51. See Steven A. Ramirez, Market Fundamentalism's New Fiasco: Globalization as Exhibit B in the Case for a New Law and Economics, 24 MICH. J. INT'L L. 831, 846-48 (2003) (observing that developing nations "have little choice but to follow the free market dictates of the IMF," and that "international economic institutions" like the IMF and the World Bank "were never intended to be the high priests of the failed laissez-faire ideology"); Crain, supra note 25, at 93 ("Starting in the eighties, developing nations found free-market doctrine written into their loan agreements: bankers refused to extend credit unless the nations promised to lift capital controls, balance their budgets, limit taxes and social spending, and aim to sell more goods abroad - an uncanny replica of the austerity terms enforced under the gold standard. The set of policies became known as the Washington Consensus.").

52. See, e.g., RoDRIK, supra note 49, at 126 (noting that "expanded trade has interacted with the macroeconomy to produce... negative consequences for wages and unemployment"); David Autor et al., The China Shock: Learning from Labor-Market Adjustment to Large Changes in Trade, 8 AnN. REV. ECON. 205, 206 ("Of course, introductory trade theory also teaches us that international trade is not generally Pareto improving. ... '[I]nternational trade tends to make low-skilled workers in the United States worse off-not just temporarily, but on a sustained basis."') (quoting PAUL R. Krugman \& Maurice ObstFeld, InTERnational EConomics: TheORY AND Policy 64 (2008)); Jeronim Capaldo \& Alex Izurieta, Trading Down: Unemployment, Inequality and Other Risks of the Trans-Pacific Partnership Agreement 19 (Tufts Univ. Glob. Dev. and Env't Inst., Working Paper No. 16-01, 2016), http://www.ase.tufts.edu/gdae/Pubs/wp/16-01Capaldo-IzurietaTPP.pdf [https:// perma.cc/3JAL-HVQH] (finding that the TPP will lead to "a contraction of GDP in the United States and in Japan, and negligible income gains in other countries" and "job losses and higher inequality in all participating economies," and that "the costs of the TPP are projected to fall asymmetrically on labor"). Even conservative voices supportive of more open trade recognize this problem. See generally The New Political Divide, ECONOMIST (July 30, 2016), https://www.economist.com/news/leaders/ 21702750-farewell-left-versus-right-contest-matters-now-open-against-closed-new [https://perma.cc/ UE3Y-HCRM] ("Those who believe in [globalization] must... acknowledge, however, where globalisation needs work. Trade creates many losers, and rapid immigration can disrupt communities. But the best way to address these problems is not to throw up barriers. It is to devise bold policies that preserve the benefits of openness while alleviating its side-effects. Let goods and investment flow freely, but strengthen the social safety-net to offer support and new opportunities for those whose jobs are destroyed. To manage immigration flows better, invest in public infrastructure, ensure that immigrants work and allow for rules that limit surges of people (just as global trade rules allow countries to limit surges in imports). But don't equate managing globalisation with abandoning it."); Paul Krugman, Trade and Inequality, Revisited, VOX (June 15, 2007), https://voxeu.org/article/trade- 
So, when what has been called the Great Recession hit, it is unsurprising that some of the same nativist sentiments that arose in the 1930s emerged in both the U.S. and EU. ${ }^{53}$ Inequality had risen in the U.S. to levels not seen since the mid-1920s and even surpassed those levels, ${ }^{54}$

and-inequality-revisited [https://perma.cc/76EU-MWW7] ("In 1995, I [] believed that the effects of trade on inequality would eventually hit a limit, because at a certain point advanced economies would run out of labour-intensive industries to lose - more formally, that we'd reach a point of complete specialisation, beyond which further growth in trade would have no further effects on wages. What has happened instead is that the limit keeps being pushed out, as trade creates 'new' labour-intensive industries through the fragmentation of production.... This doesn't mean that I'm endorsing protectionism. It does mean that free-traders need better answers to the anxieties of those who are likely to end up on the losing side from globalization."); see also Crain, supra note 25 , at 93 ("[A]lthough free trade benefits a country over all, it almost always benefits some citizens more thanand even at the expense of-others. The proportion of low-skilled labor in America is smaller than most countries that trade with America; economic theory therefore predicts that international trade will, on aggregate, make low-skilled workers in the United States worse off.").

53. Edward D. Mansfield et al., Effects of the Great Recession on American Attitudes Toward Trade, BRIT. J. POL. SCI. 1, 1 (2016), http://iscap.upenn.edu/sites/default/files/effects_of the great recession_on_american_attitudes_toward_trade $\% 20 \% 281 \% 29 . p d f \quad$ [https://perma.cc/Y7U4-D555] (finding that, during the Great Recession, Americans "working in import-competing industries who lost their jobs" grew more hostile to trade and that, "most importantly, increasing anxiety that foreign commerce would harm people in the future, even if it had not done so thus far, contributed to mounting opposition to trade among the American public"); Yann Algan et al., The European Trust Crisis and the Rise of Populism 14-29 (Eur. Bank for Reconstruction and Dev., Working Paper No. 208, 2018), https://papers.ssrn.com/sol3/papers.cfm?abstract_id=3128274 (showing a post-Great Recession rise in populist parties that "share a criticism of European supranational integration and a call for a return to supremacy of nationalism"). See generally Crain, supra note 25, at 92 (discussing how no populist leader-"define[d] as a politician who is anti-elite, authoritarian, and nativist-took office during th[e] golden era [during the three decades following the Second World War], and that a far narrower share of votes went to extremist parties than before or after") (citing BARRY EICHENGREEN, THE POPULIST TEMPTATION (2018)) (internal quotations omitted); Kuttner, supra note 38 ("For three decades [following Bretton Woods in 1944], the West combined high rates of growth with increasing equality and security for ordinary citizens. But a major shift in both power and dominant ideology has turned the global marketplace back into something more like the pre-Roosevelt system. 'Trade' deals have been deployed to dismantle managed capitalism. Working people have not only suffered; they have lost confidence in globalist elites - and worse, in government itself and even in democracy. This is a system-wide pathology. That's why the backlash, and the embrace of ultra-nationalist strongmen, looks so similar throughout the West. The more that bien pensants double down on globalization, the more defections they invite and the more leaders like Trump we get.").

54. Erik R. Stegman, Introduction and Summary, in ResetTing the Poverty Debate: RENEWING OUR COMMITMENT TO SHARED PROSPERITY 4 (2013), https://cdn.americanprogress.org/ wp-content/uploads/2013/10/HalfInTen_2013_CAP1.pdf [https://perma.cc/ZV6T-WJ28] ("Most importantly, income inequality is at its highest level since the 1920s, and it has been getting worse even as our economy grows after the Great Recession. This is a far cry from the era of broadly shared growth and prosperity in the decades immediately after World War II.") (citing Chad Stone et al., $A$ Guide to Statistics on Historical Trends in Income Inequality, CTR. ON BUDGET \& POL'Y PRIORITIES (2013), http://www.cbpp.org/cms/?fa=view\&id=3629 [https://perma.cc/N9EK-2C5J]); see also Sheldon DanZiger et AL., POVERTy AND the Great ReCESSion 5 (2012), https://inequality. stanford.edu/sites/default/files/Poverty_fact_sheet.pdf [https://perma.cc/LWD5-EYDQ] ("The last time poverty was as high as it is now was in the early 1980s."); Mark Sheskin, The Inequality Delusion, NEw SCIENTIST, Mar. 31, 2018, at 28 ("Take the wealth of the eight richest people on the planet and combine it. Now do the same for the poorest 3.5 billion. The two sums are the same: $£ 350$ billion. 
and the recovery from the Great Recession did not reduce that growing tendency. Instead, it deepened as the benefits of a globalizing economy flowed more and more to an elite few. ${ }^{55}$ Economic insecurity increased as more and more people feared that they and their children would be unable to match the lifestyles led by their parents. Stagnation and even a decline in real wages over a quarter century gave an empirical basis to this concern. ${ }^{56}$ So did the ever growing gap between the wealthy elites and the rest of society.

Correct: just eight people own as much wealth as half of the world's population."); David Cole, Taxing the Poor, N.Y. REV., May 10, 2018, at 25 ("The New Deal ... introduced price controls, wage and workday regulations, and other protections of workers and consumers from exploitation by big business. In part because of these reforms, America after World War II entered a period in which prosperity was shared fairly widely, and the middle class grew. In 1928, for example the top 10 percent of earners took home 46 percent of the nation's income, not including capital gains. From 1951 to 1982 , however, the top 10 percent's share never hit 33 percent. Government subsidies supported home buying for all and college education for millions of veterans. The poverty rate dropped markedly, reaching a low of 11 percent in 1973. Following a major agreement in 1950 between auto workers and General Motors, businesses began providing pensions and health insurance for their employees. And the income tax during this period was truly progressive: the top marginal tax rate was 88 percent in 1942, 91 percent from 1951 to 1963, and remained above 70 percent until 1981. Under Trump's tax cut, by contrast, the top rate will drop to 37 percent. Since the late 1970's, income and wealth disparities have once again grown dramatically. In 2017, the richest 10 percent of Americans owned 77 percent of the nation's wealth, a higher proportion even than in the Gilded Age. Today, the twenty richest Americans have more wealth between them than the bottom half of the US population-some 152 million people. In 1979, CEO's of America's most successful businesses earned, on average, about thirty times as much as their workers. By 2013, they earned almost three hundred times as much. And in the thirty-year period from 1979 to 2008, the top 10 percent of Americans received 100 percent of the benefits from growth in income, while the incomes of the bottom 90 percent fell."); Christina M. Gibson-Davis \& Christine Percheski, Children and the Elderly: Wealth Inequality Among America's Dependents, 55 DEMOGRAPHY 1009, 1011 (2018) ("Wealth inequity has risen tremendously in the United States over the past half-century. In 1962, the top $20 \%$ of the wealth distribution accounted for $81 \%$ of all wealth; by 2013 , that share had risen to $89 \%$. Wealth inequality was relatively flat between the 1960s and early 1980s, rose steeply in the 1980s, plateaued in the 1990 s and early to mid-2000s, and then increased sharply with the onset of the Great Recession. Increases in wealth inequality appear to be driven by those at the very top of the wealth distribution (the so-called $1 \%$ ). Between 1983 and 2013, the top $1 \%$ had net worth gains of $40 \%$, while those in the bottom $80 \%$ had decreases of $-0.01 \%$. .) (citations omitted).

55. Timothy Meyer, Saving the Political Consensus in Favor of Free Trade, 70 VAND. L. REv. 985, 988-89 (2017) ("[N]inety-five percent of the economic gains during the recovery from the financial crisis of 2007 have gone to the richest one percent of society."); Jesse Bricker et al., Changes in U.S. Family Finances from 2010 to 2013: Evidence from the Survey of Consumer Finances, 100 FED. RES. BULL. 1, 6-8 (2014) ("By percentile of net worth . . both mean and median income fell [between 2010 and 2013] for those in the bottom three quartiles, while both measures rose for the top quartile."); Andrew J. Bacevich, Saving "America First": What Responsible Nationalism Looks Like, FOREIGN AFF., Sept.-Oct. 2017, at 62 ("True, since the end of the Cold War, globalization has created enormous wealth. But it has also exacerbated inequality.").

56. Patricia Cohen, Paychecks Lag as Profits Soar, and Prices Erode Wage Gains, N.Y. TIMES (July 13, 2018), https://www.nytimes.com/2018/07/13/business/economy/wages-workers-profits. html [https://perma.cc/K8ZH-BK47] (documenting stagnate wage growth and growing corporate profits). 
The emergence of parties like the UK Independence Party (UKIP) in the United Kingdom clamoring for Brexit, and the successful candidacy of Donald Trump in 2016 were long in coming. Learned commentators had argued for many years that failing to address the economic anxiety being produced by globalizing trade without globalizing protections for workers would lead to bad results. ${ }^{57}$

And poll data from the United States and the EU demonstrate that economic insecurity was central to the appeal of movements like Brexit and to the election of Donald Trump. ${ }^{58}$ When economic insecurity was profound, arguments that blame the "other"-foreign workers, global elites, and so forth-have fertile ground in which to flower, and flower they did. ${ }^{59}$

57. A good example is reflected in a scholar's description of Labor Secretary Reich's still relevant thoughts of over a decade ago. Ruggie, supra note 43, at 1 ("Outgoing United States Labor Secretary Robert Reich, in a January 1997 address, maintained that the second Clinton administration's 'unfinished agenda is to address widening inequality' in America. Indeed, he questioned whether the United States was abandoning 'the implicit social contract' it had maintained with workers for half a century. Technological advances and global economic integration, he noted, 'tend to reward the best-educated and penalize those with the poorest education and skills,' and government policy had not yet effectively responded to the new economic realities.").

58. See Heather Stewart, UK Politics Becoming Mired in 'Culture Wars,' Study Suggests, GUARDIAN (Dec. 7, 2016), https://www.theguardian.com/politics/2016/dec/07/study-finds-uk-politic s-mired-culture-wars-brexit-donald-trump [https://perma.cc/Y5QZ-C3H8] ("60\% of people who said the[y] were 'just [] getting by' [financially] voted to leave the EU, as did $70 \%$ of those who said they were 'finding it quite or very difficult."); ROBERT GRIFFIN \& RUY TEIXEIRA, THE STORY OF TRUMP'S APPEAL: A PORTRAIT OF TRUMP VOTERS 8 (2017) (“Among general election voters, Trump supporters were twice as likely as Clinton supporters to have said their personal finances were getting worse (52 to 26 percent) and four times as likely to have said the economy was getting worse (59 to 15 percent). And on both of these questions, 40 percent of Obama to Trump switchers thought things were getting worse."); see also Autor et al., supra note 52, at 225 (arguing that the adverse effects of international competition to American workers varies by region, and suggesting that the Midwestern states on which the 2016 election turned were among those most negatively affected by trade with China between 1990 and 2007). As of this year, at a time of low unemployment, but not fast-growing wages, the economic anxiety of Americans in battleground states still exceeds their optimism on almost every dimension. See Stanley Greenberg, The Broad Support for Taxing the Wealthy, AM. PROSPECT (June 20, 2018), http://prospect.org/article/broad-support-taxing-wealthy [https://perma.cc/W9DQ-8U7G] (citing April 2018 polling data to this effect).

59. I understand that there are those who agree that a desire to preserve a certain sense of culture, not economic insecurity, is driving national sentiment and support for anti-immigration and antiinternational sentiment. See, e.g., Matthew Wright et al., Conflict and Consensus on American Public Opinion on Illegal Immigration 7 (Am. Univ. Sch. of Pub. Aff. Research Paper No. 2014-0006, 2014) ("Perceived threats to a country's distinctive identity and culture drive anti-immigrant sentiment in the U.S. and elsewhere."); Dara Lind, The Research That Made Me Take Donald Trump Seriously, Vox (May 4, 2016), https://www.vox.com/2015/7/29/9060427/nativism-research-immigration-trump [http s://perma.cc/F59F-WB6H] ("For many white Americans-the Republican Party's most important constituency, in both the primaries and the general election-immigration isn't as simple as legal versus illegal. Their primary concern is preserving American culture."). But, it seems to me that there is a strong relationship between economic and cultural insecurity. If working and middle class people felt secure that they and their children would make a good living, the threat they perceive from outsiders would be minimized. In fact, there is data that shows that cultural, national sentiment is high 
And because the center left parties had no robust answer to addressing this insecurity, their natural base-working people-were tempted to break away, particularly when they found themselves less able to identify with the Davos Democrats arguing that everyone should just assume that a globalizing economy was a good thing. ${ }^{60}$ The concerns of that crowd, however high minded, seemed to be rather high class problems compared to formerly middle class families facing downward decline and hearing no promise of how their lives would be better than, or even as good, as the lives their parents had led.

All of this would have seemed natural to Berle. To ignore the centrality of economic security to a stable domestic society and world order was to disregard everything Berle knew to be most important.

\section{III.}

The next topic of current relevance involves whether government has the duty and capacity to act to make sure that the economy provides economic security for the many. This is an easy topic to cover as it relates to Berle.

in areas with low immigrant populations but high economic insecurity: PEW RESEARCH CTR., Modern IMmigration Wave Brings 59 Million to U.S., Driving Population Growth and ChANGE THRough 2065: VIEW OF IMMigration's IMPACt ON U.S. SOCIETY MiXed 54 (2015), http:// www.pewresearch.org/wp-content/uploads/sites/5/2015/09/2015-09-28_modern-immigration-wave REPORT.pdf [https://perma.cc/XM5L-7V69] ("U.S.-born adults who live in places with immigrant communities feel more positively about immigrants. About half (45\%) of this group say immigrants make American society better in the long run, compared with $33 \%$ of those who say there are no immigrants living in their community."); $i d$. at 53 (finding that $46 \%$ of respondents to the survey with no post-high school education believe that immigrants to the U.S. are making American society worse, as compared to the $64 \%$ of respondents with bachelor's degrees or more who believe that immigrants are making American society better); Bradley Jones, Support for Free Trade Agreements Rebounds Modestly, but Wide Partisan Differences Remain, Pew ReS. CTR. (Apr. 25, 2017), http://www. pewresearch.org/fact-tank/2017/04/25/support-for-free-trade-agreements-rebounds-modestly-but-wi de-partisan-differences-remain/ [https://perma.cc/6TP4-VGV9] ("[O]pinions about the effects of free trade agreements on the country and the effects of trade on people's personal finances are linked: $70 \%$ of those who say free trade agreements are good for the country also say they have been helped financially by such agreements and a similar share (74\%) of those who say these agreements are a bad thing say they have been hurt."); Eur. COMM'N, SPECIAl Eurobarometer 461, Designing EUROPE'S FUTURE 26 (2017) ("The more difficulties a respondent has in paying household bills, the less likely they are to say globalization is positive: $39 \%$ of those with the most difficulties say this. Compared to 57\% with the least difficulties."); see also Marco Becht \& Luis Correia da Silva, External Financial Markets Policy: Europe as Global Regulator?, in FRAGMENTED POWER: EUROPE IN THE GLOBAL ECONOMY 200, 229, 248, 252 (Andre Sapir ed., 2007) (citing reasons why immigration of low-skilled, low-cost workers can hurt low-skilled and blue collar workers of the host country, in terms of unemployment and downward pressure on wages).

60. Kuttner, supra note 38 ("Elites of both parties won the policy debates on trade, but lost the people. By 2016, millions of working people whose families had once reliably supported Democrats had defected to the Tea Party and then to Trump. Across the Atlantic, their counterparts were deserting social democrats to support far-right nationalist parties. Conflicts over refugees and over identity compounded the backlash, but it was basically economic."). 
With the stagnation of wages in the U.S. and EU for working people, growing inequality, and the absence of any indication that the admonitions of the ILO or other international bodies has sufficed to protect the clout of workers, one imagines that Berle would be impatient without moving beyond the current impasse to the recognition of a reality that he had already accepted in his lifetime: ultimately, government regulation of the economy to make sure it serves all fairly must be co-extensive with the scope of that economy. The argument that workers' rights should be subordinate to those of mobilized capital and that a world economy should be premised on giving a huge club to capital, and kind, non-binding words to labor involves a belief that the world should return to its pre-New Deal state.

Consistent throughout Berle's writings from the 1930s onward was an unwavering belief that addressing the legitimate desire of working people to have stable work, a roof over their head, health care, and a secure retirement was fundamental to a just society. ${ }^{61}$ Berle went even further and argued that after the New Deal and the investments society had made in increasing private sector profitability, the stockholders of corporations could not claim to be any more entitled to hog those profits than society generally. ${ }^{62}$ In fact, in an early article in The New Republic, Berle argued for moving toward a system of production in which most of the gains went to managers and workers, with passive stockholders limited to receiving a

61. See, e.g., The Quest for Individual Security, supra note 7, at 406.

62. See generally Adolf A. Berle, Jr., "Control” in Corporate Law, 58 Colum. L. Rev. 1212 (1958). 


\section{limited return. ${ }^{63}$ The division of income between labor and capital that Berle cared about remains a huge issue in today's economy. ${ }^{64}$}

63. Adolf A. Berle, Jr., How Labor Could Control, 28 NEw RePuBlic 37 (1921). He explained his thinking this way:

Where [stockholders] actually do manage, throwing in brains and judgment and skill with their money they render a service entitling them to more than simple interest on their money. As a matter of plain fact however [stockholders] usually do not manage; they sign a proxy which comes around once a year in the mail. A small group do manage and earn much of what they receive; but the larger proportion merely buy, hope, hold and cash in when they can, reaping where they did not sow. The use of their money is worth the current rate of interest; the value of their management is nil. Everything over interest is unearned increment — which is merely another way of saying earned by someone else; someone who did not get all he earned — or, to speak plainly, by the men who worked in the corporation's mills or mines.

Just here it becomes possible to think of a businesslike end to the economic war. Who are the people who have a right to capitalize the hope of the plant's earnings? Who are the people who can decently gamble on their output? Who are the people who have most right to ask for control of the plant? The answer is obviously in favor of the staff of the plant, including, of course, the chairman of the board, the directors, as well as the oilers and feeders and loomfixers. That the large majority of employees should have to spend their spare time devising means to fight the control of their own plant is simple foolishness.

Id. The rest of the article argues in essence for concentrating most of the effective economic ownership and control of corporations in their managers and workers on a cooperative basis. $I d$. The excellent article by Professor Hendrickson in this symposium underscores several of these points. Mark Hendrickson, "In Time of Stress, a Civilization Pauses to Take Stock of Itself": Adolf A. Berle and the Modern Corporation from the New Era to 1933, 42 SEATTLE U. L. REv. 361 (2019) (stressing Berle's focus on ensuring that the workers of corporations were fairly treated as the separation between stock ownership and control widened, noting Berle's proposal to create a company controlled by its workers and managers, highlighting Berle's view that it was critical that government act to make sure the economy worked for the many, and saying that Berle's later more sanguine view of corporations and the growth of institutional investors was rooted in his belief that they had been regulated such that although the economic system was not socialized in terms of ownership, it had acted to "socialize income" and to provide a good living for the many). Berle's thinking is echoed in current examples such as the German system of co-determination, where labor influence on both boards and workers' councils exemplifies many of the concerns voiced by Berle. See, e.g., Mark J. Roe, Some Differences in Corporate Structure in Germany, Japan, and the United States, 102 YALE L.J. 1927, 1970 (1993) (arguing that co-determination "injects employees-white collar, blue collar, and union-representedinto the boardrooms of the largest German firms," and that "[w]hile American politics fragmented capital and labor, German politics brought them together in the boardroom.").

64. A thorough study prepared by the International Labour Organization for the G20 Employment Working Group in 2015 documented: (i) the decline in the comparative share of national wealth going to workers in the G20 nations during the period from 1970 to 2014; (ii) a corresponding increase in overall economic inequality; and (iii) the fact that both of these factors are present in the United States and that workers' share of the national wealth in the United States is at a level lower than that reached in the 1930s. INTERNATIONAL LABOUR ORGANIZATION, THE LABOUR SHARE IN G20 ECONOMIES 6, 7, 11 (2015); see also Jeff Stein, Federal Reserve Chair: Decline in Worker Share of National Economy 'Very Troubling,' WASH. POST (July 17, 2018), https://www.washingtonpost.com/ business/2018/07/17/federal-reserve-chair-decline-worker-share-profits-very-troubling/?noredirect= on\&utm_term=.7c48110964a6 [https://perma.cc/4LRQ-3XG5] (reporting that Federal Reserve Chair Jerome Powell testified before the Senate Banking Committee that "the share of the national income going to American labor had fallen 'precipitously' for more than a decade and was not reversing course" and that "[i]n the last five years or so, labor share of profits has been sideways . . very much akin to the flattening out of median incomes over the last few decades"). 
Without the investments and policies of the polity, private industry would not, in Berle's view, be anywhere as wealthy and profitable as it was, ${ }^{65}$ and therefore it was fitting that the private sector act responsibly to make the economy work for the many. ${ }^{66}$ As he wrote in 1965 :

Corporations derive their profits partly indeed from their own operations, but partly also from their market position and increasingly from techniques resulting from state expenditures of taxpayers' money. In this sense, the American state is an investor in practically every substantial enterprise; without its activity, the enterprise, if it could exist at all, would be or would have been compelled to spend money and effort to create position, maintain access to market, and build technical development it currently takes for granted. Under these circumstances, there is little reason or justification for assuming that all profits should automatically accrue to stockholders. Put differently, stockholders - not having created the entire enterprise - are no longer the sole residuary legatees (after production costs and depreciation) of all the profits of an industrial progress, much of which is derived from state outlay. ${ }^{67}$

In the final chapter of his iconic book with Gardiner Means, Berle argued that, like other forms of power over society, those who wielded economic power must be accountable for exercising it in a way that was fair to all. ${ }^{68} \mathrm{He}$ argued that the separation of ownership and control counseled for the adoption of a "wholly new concept of corporate activity," in which:

65. See A. A. Berle, Jr., The Government in Business, 1 VitAL SPEeChes of THE DAY 839, 83940 (1935) (arguing that "[m]ost business in the country got its start with government assistance," that those who argue that government should stop regulating business are the most likely to have benefited from special legislation, that many lines of business are more public than private, and that a "government which is not concerned with business simply cannot survive").

66. Berle had little time for the post-war advocates of laissez-faire, even those from the "Chicago school," who he viewed as ignoring history and as taking credit for successes that were in fact due to the New Deal/Social Democratic modification to capitalism. Adolf A. Berle, Modern Functions of the Corporate System, 62 Colum. L. REv. 433, 433-37 (1962); see also id. at 442-44 (disagreeing with strong advocates of stockholder profit maximization like Professor Henry G. Manne and arguing that competitors are entitled to engage in socially responsible pursuit of profit that involves fair treatment of their workers and public-regarding behavior).

67. Property, Production and Revolution, supra note 9, at 9; see also Government Function, supra note 7, at 37 ("It should be possible, if sufficient care be taken in constructing institutions, to make possible that direct intervention in economic activity which may be required at any given time to stabilize and improve economic conditions, without thereby impairing anyone's liberty of choice. Perhaps it is not too much even to hope that enlightened private enterprise will be drawn to see that this sort of activity is as vital to their economic life as it is to the political life of the state. It is, in fact, the only possible insurance against the cataclysmic movements which have eliminated liberty and individual enterprise alike on the Continent of Europe.").

68. Adolf A. Berle, Jr. \& Gardiner C. Means, The Modern Corporation and Private PROPERTY 356 (Macmillan 1933) (1932). 
[n]either the claims of ownership [i.e., stockholders'] nor those of control [i.e., corporate managers'] can stand against the paramount interests of the community. The present claims of both contending parties now in the field have been weakened by the developments described in this book. It remains only for the claims of the community to be put forward with clarity and force. Rigid enforcement of property rights as a temporary protection against plundering by control would not stand in the way of the modification of these rights in the interest of other groups. When a convincing system of community obligations is worked out and is generally accepted, in that moment the passive property right of today must yield before the larger interests of society. Should the corporate leaders, for example, set forth a program comprising fair wages, security to employees, reasonable service to their public, and stabilization of business, all of which would divert a portion of the profits from the owners of passive property, and should the community generally accept such a scheme as a logical and human solution of industrial difficulties, the interests of passive property owners would have to give way. Courts would almost of necessity be forced to recognize the result, justifying it by whatever of the many legal theories they might choose. It is conceivable,--indeed it seems almost essential if the corporate system is to survive,- - that the "control" of the great corporations should develop into a purely neutral technocracy, balancing a variety of claims by various groups in the community and assigning to each a portion of the income stream on the basis of public policy rather than private cupidity. ${ }^{69}$

Berle was a believer in economic progress and scientific advancement, but he knew that both could be disruptive to businesses and workers threatened by them. He thought it was a just society's duty to help businesses and workers thrive, something he spoke about in 1943, when he said the function of an enlightened government managing a modern economy:

First: That every government, and particularly every democratic government, will be under an impulsion to attempt to provide for the economic needs of substantially all its people;

Second: That the method will be an attempt to assure substantially general opportunity for useful work at adequate pay, accompanied by social security provision for the nonproductive periods of life, including childhood, maternity, sickness, and old age;

Third: That whenever any substantial gap appears in the generality of the provision achieved, government will be under pressure to fill 
that gap through direct entry into economic activity heretofore commonly carried on by nongovernmental agencies;

Fourth: That economic readjustments in large countries may be presumed to create problems of such magnitude that purely private activity cannot provide for them. ${ }^{70}$

For a society like the United States committed to individual liberty, including the ability to engage in commerce for personal gain, he argued that: "A free and democratic government will seek full employment, but only under conditions which give the maximum possible choice of life to the individuals composing its state; and its direct entry into the economic field will always be restrained by this consideration." ${ }^{, 71}$ Thus, in addressing the dislocations produced by economic dynamism, such as the increased ability of machines to produce more with less labor, Berle argued that for that reason:

[F]ree governments, as they have obeyed the impulsion to enter the economic field and to provide full employment and activity for their people, have sought, in order:

1. Methods by which the individual was assisted to enter new fields of production: for instance, the land grant policy followed after the American Revolution, and in economic crises during the nineteenth century.

2. Indirect encouragements to provide enterprise in the hope that this stimulation would provide the necessary activity and employment: tariffs, indirect subsidies, temporary monopoly, such as patent rights, and the like. This intervention, forecast in Hamilton's report on manufactures, was the norm during the latter part of the nineteenth century and through to 1930 .

3. Direct intervention in the economic field, but oriented toward private individual and enterprise, and carried out through direct financial assistance. This was the policy to which President Hoover's government was eventually driven when the Reconstruction Finance Corporation was formed, when the Federal Reserve banks were empowered to make direct loans to industry, and when a program of railroad aid was commenced.

4. Direct entry into economic fields, limited, however, strictly to nonprofit or nonprivate operations, such as conventional public works (roads, bridges, public buildings,

70. Government Function, supra note 7, at 27.

71. Id. at 32 . 
and so forth), with which must also be bracketed low rent, public-assisted housing, and certain other similar operations in fields which for one reason or another private activity was unable or unwilling to occupy.

5. Direct intervention in direct production in certain fields in which government is able to work, but in which private enterprise is also able to work, for the purpose, largely, of assuring that the work shall be done and the production made available at times and under circumstances in which for one reason or another (perhaps temporary), private activity is unable or unwilling to advance. ${ }^{72}$

In Berle's view, government could advance societal wealth and full employment through strategic investments in economic growth and sound incentives for socially useful behavior by businesses. Berle was also bullish on our ability to generate more abundant wealth and to have it shared more widely. ${ }^{73} \mathrm{He}$ advocated that the wealth being amassed be deployed to fund the infrastructure and social and cultural institutions necessary to a modern economy, ${ }^{74}$ and he argued that it was not coincidental that wealthier communities tended to be the ones where investments in these areas had been made. ${ }^{75}$ Thus, in an article in 1960, he called for a focus on the revitalization of major urban areas and contended that the wealth that was being placed in pension and mutual funds could

72. Id. at 32-33

73. See Welfare of the Masses, supra note 7, at 469 (arguing that tax systems should "assure that economic growth does not merely make the rich richer" and that ownership of industry "be spread as widely as possible"); A. A. Berle, Jr., The Law and the Social Revolution, 22 SURV. GRAPHIC 592, 593 (1933) [hereinafter The Law and the Social Revolution] ("A question has been asked, and that question has not been answered. The question is, why, in a civilization over-full of material things, more than able to supply every human need, the organization of economics leaves millions upon millions of people in squalor and misery? Since it seems that private interests cannot, or, at all events, do not, solve this problem by achieving a balance, the insistence is that the state erect a form of law so changing the machinery of production and distribution that human needs throughout the country will be approximately satisfied.").

74. Reflections on Financing Governmental Functions of the Metropolis, supra note 9, at 77-78 ("We are beginning to learn that a modern economy cannot continue running at the rate of productivity and speed needed to keep it above water unless a substantial margin is devoted to ends which we call 'altruistic' - over and above calculations of personal profit or advantage.... The corollary of this, however, is that these altruistic activities - now seen not to be a net cost but a net support and accretion - have to do with the economy of the entire United States. Like the keystone of an arch, they both hold and are held. They take in and they feed out, and their line has gone out to the entire country. 'Federal aid' is not a local enterprise; properly handled in the great metropolitan areas, it is a solid support for a large part of the American economy."); see also Private Property, supra note 7.

75. Reflections on Financing Governmental Functions of the Metropolis, supra note 9, at 78 ("The great metropolitan areas offer golden opportunities for just this kind of activity-indeed their organization almost compels such economics. It is not accident that the communities which have existed or exist alongside of great altruistic neighbors such as great universities, great museums, or great churches are commonly far more prosperous than those which do not."). 
be well deployed to fund that worthy project. ${ }^{76}$ And to this point, in 1964, Berle argued that the "American economic system now permits, and social morality demands, a new huge advance of comparable proportion" to the New Deal but involving an even "larger vision[] of the content of life."77

IV.

It is equally easy to show that Berle would reject exiting from international engagement as an answer to economic insecurity arising from commercial dynamism in a globalizing economy. ${ }^{78}$ Berle viewed the turtle approach to security as outdated six decades ago. In 1954, he wrote:

A comparatively small country with determination, will, and a devoted population handling its economic life without too much reference to the neighboring areas could, two centuries ago, put enough force into the field to stand off even the more powerful neighbors, and could maintain a cultural life satisfying its people and often contributing brilliantly to the world. But mid-twentieth-century scientific progress has shredded the former situation into its component parts. ${ }^{79}$

Even during this period of American hegemony, he believed that the United States itself would suffer if it tried to disengage from the world economy, noting:

Modern economics, as noted, make it practically impossible for any state, even the largest, to exist at a tolerable economic level except as

76. Id. at 77-78 ("We are beginning to learn that a modern economy cannot continue running at the rate of productivity and speed needed to keep it above water unless a substantial margin is devoted to ends which we call 'altruistic'-over and above calculations of personal profit or advantage."); see also And What Shall We Do Then?, supra note 9, at 102 (arguing for the use of public works and urban reconstruction as a critical part of reorienting the war economy to promote peaceful prosperity).

77. Adolf A. Berle, Jr., Intellectuals and New Deals, NEw RePUBLIC, Mar. 7, 1964, at 21, 24 (reviewing STERNSHER, REXFord TUGWELL AND THE NEW DEAL (1964)).

78. E.g., Adolf A. Berle, Jr., Other Forces Which Determine Our Foreign Policy, 1 VITAL SPEECHES OF THE DAY 415 (1935) [hereinafter Other Forces Which Determine Our Foreign Policy] ("Manufactured goods and agricultural products have for some centuries flowed fairly freely throughout the world. It became absolutely necessary for them to do so when the western European countries, such as Italy, Germany and Great Britain, developed populations larger than could be supported with the agricultural products of their own land. They had to buy raw materials; they had to manufacture; they had to sell abroad; and they had to import food. Cut that chain and you get a slow process of starvation. In point of fact, there is not a great deal of difference between a tremendously high tariff war cutting England off from her export trade and a submarine campaign torpedoing foodships as they come in. The latter is more dramatic and a little swifter, but the effect is much the same."); Adolf A. Berle, Jr., Cooperative Peace in the Western Hemisphere, 1 DeP'T ST. Bull. 659, 663 (1939) (arguing for the importance of mutually advantageous trade agreements among nations in the Americas not just for the good of business, but also for the "promise of economic stability" in all the participating nations).

79. The Soviet-Chinese Complex, supra note 12, at 67. 
part of a complex of many other countries. Were the United States, for example, cut off from all foreign commerce, the economy of America would drop in six months' time to a level few of us would tolerate; and in the process at least a dozen other countries would be reduced to collapse. Were smaller countries, say Great Britain or Germany (let alone the Netherlands), thus circumscribed, their peoples would approach starvation. ${ }^{80}$

Given that the extent of international trade has grown enormously since that time, ${ }^{81}$ and that the U.S. economy is now heavily dependent on international trade, ${ }^{82}$ it is hard to imagine that Berle would now disclaim his prior belief that:

The capacity to produce a stable system of international economics is likely to determine also how solid a force the Free World really is. Great parts of South and Central America at this moment find that their fate lies in the dubious balance of certain world prices (notably, coffee, cotton, copper and wheat) and of continued consumption of their oil. They are demanding stabilization exactly as American farmers demand stabilization of agricultural prices, but for more reason: their lives are at stake. Other parts of the Free World also depend for their economic life on the United States: this is particularly true at the moment of Great Britain. ${ }^{83}$

80. Basic Elements, supra note 11, at 426; see also id. ("Economically, few countries, if any, are now sovereign save in name.").

81. See generally World Trade Org., World Trade RePOrt 2017: Trade, TechnOlogy AND JOBS 16-18 (2017), https://www.wto.org/english/res_e/booksp_e/world_trade_report17_e.pdf [https://perma.cc/4ESN-XYLF] ("[T]he international economic system established after the Second World War was purposely designed around the interlinked objectives of open trade and integration, on the one hand, and full employment, social security, and mass public education, on the other . . . Indeed, the evolution of the global economy over the past century, especially since 1945, has generally been accompanied not by a retreat of government but by its advance at the national and international level, providing the institutions, rules, regulations and social safety nets that are increasingly indispensable - along with less formal social and cultural institutions and networks- for the functioning of sophisticated and complex market economies.").

82. See generally Bus. ROUndtable, How thE U.S. ECONOMY Benefits From INTERNATIONAL TRADE \& INVESTMENT 1 (2015), http://businessroundtable.org/sites/default/files/ BRT_TRADE_2015_US.pdf (explaining that international trade supports 41 million U.S. jobs; that the U.S. exported $\$ 1.6$ trillion in goods and $\$ 710.6$ billion in services in 2014 ; and that free trade agreements facilitate rapid export growth from the U.S.); CHRISTOPHER WILSON, HOW TRADE WITH MEXICO IMPACTS EMPLOYMENT IN THE UNITED STATES 1 (2016), https:/www.wilsoncenter.org/ sites/default/files/growing_together_how_trade_with_mexico_impacts_employment_in_the_united states_2.pdf [https://perma.cc/WA3G-DERZ] ("[O]ne out of every 29 U.S. workers has a job supported by U.S.-Mexico trade . . . . [I]f trade between the United States and Mexico were halted, 4.9 million Americans would be out of work."); U.S. CHAMBER OF COMMERCE, THE FACTS ON NAFTA 1 (2017), https:/www.uschamber.com/sites/default/files/the_facts_on_nafta_-_2017.pdf [https:// perma.cc/5QX3-9TEN] ("Trade with Canada and Mexico supports nearly 14 million American jobs, and nearly 5 million of those jobs are supported by the increase in trade generated by NAFTA.").

83. Basic Elements, supra note 11, at 434. 
Nor would he likely retreat from his call for the U.S. to engage in "deep[]" and "fundamental[]" thinking about building and strengthening international institutions that would put in place global plans to address the universally felt need of human beings for economic security ${ }^{84}$ :

The time has come when, I think, both the West and the East are likely to consider seriously reasonable global plans. This is not because of sudden conversion to internationalist faith. It is, quite simply, because the forces with which we all work, whether in economics or in international ballistic missiles, are themselves worldwide — and no other solutions make sense. ${ }^{85}$

Another bit of realism would weigh on Berle. Berle is famous for his work focusing on the problem of constraining corporate power in a society that had not yet created a national system of economic regulation that could hold corporations fairly accountable to society for operating in a manner inconsistent with societal values and needs ${ }^{86}$ Given that, it would seem logical that with the emergence of huge corporations that in reality have no national identity ${ }^{87}$-as exemplified most easily by the inversion

84. Id. at 435 .

85. Id.

86. See, e.g., Nicholas Lemann, Transaction Man: The Rise of the Deal and the DECLINE OF AMERICA (2019) ("[What] Berle had really wanted was to enhance the power of the government to the point where it could outmatch the power of the corporation. He had no quarrel with centralized power, as long as it was used for good. The drama of his career was the harnessing of the corporation, not its destruction; indeed, in order to work, his vision of a good society actually required that corporations be as big and powerful as possible."); Adolf A. Berle, Jr., Corporate DecisionMaking and Social Control, 24 Bus. LAW. 149, 152 (1968) ("The corporate system of our time . . can and should conform to social requirements; it can and should lend help to government and to quasipublic and other institutions whose task is to develop a society both good and just.").

87. See, e.g., Adolf A. Berle, JR., Economic Power AND the Free Society 12 (1957) [hereinafter FREE SOCIETY] (Some large corporations "can be thought of only in somewhat the way we have heretofore thought of nations. Whether we like it or not, this is what has happened.... The dangers are obvious. But history cannot usually be reversed," and that "a body of doctrine which will control power" is needed to deal with the growing power of those corporations.); Adolf A. Berle, Jr., Corporations and the Public Investor, 20 AM. ECON. REV. 54, 58 (1929) (arguing that it was critical to address the growth of large corporations because many of them were more economically important than individual U.S. states, and noting that AT\&T alone would have been the 27th richest state in the nation itself, on the basis of its wealth); Adolf A. Berle, Jr., Corporate Decision-Making and Social Control, 24 Bus. LAw. 149, 149-50 (1968) ("Transition of the large corporation from a private enterprise to a social institution has now been accomplished and is generally recognized. Their size, breadth of power and unlimited scope dominate the American economic scene.... A few hundred corporations dispose of more than two-thirds of America's enormous non-governmental economic activity, and their number tends to diminish though the volume of economic activity steadily increases.... Whereas, a generation ago, the law was preoccupied with assuring that managements did not victimize their shareholders, preoccupation today is with the extent of their social and political and economic responsibility for the health of the American economic machine, and for employment and welfare of its citizens."); Adolf A. Berle, Jr., The Corporation as Revolutionary, BUS. WEEK, Mar. 7, 1970, at 6 ("Americans are discovering the rapid emergence of a discernible 'world economy.' In many respects American business is only equivocally bound to the American state."). 
trend $^{88}$ - he would have an even stronger desire to create a globally effective system of economic regulation. ${ }^{89}$ Otherwise, the very mismatch that he thought characterized the pre-New Deal era would simply return, but with corporations being even more difficult to constrain, because they would no longer be rooted in any deep way in any nation, much less a particular community.

But, Berle's realism was never valueless. As important to the lack of realism involved in retrenchment, that sort of retrenchment would involve pitting the working people of each nation against each other, as opposed to finding ways to work together to make the world a better place for all. Like Martin Luther King who believed that "the arc of the moral universe is long but it bends toward justice," ${ }^{90}$ Berle viewed that the arc of history favored political forces:

(1) which tend to approach universality within their field of application; and

(2) which give to individuals a sense of harmony with the universal pattern. ${ }^{91}$

By contrast, Berle believed that the "natural selection" processes relevant to human political development "discard[] political forces":

(1) which are based on limitative conceptions such as exclusion, aggrandizement, hatred, and the like; and

(2) which tend to concentrate power without modifying that power by imposing, in some form, corresponding responsibility. ${ }^{92}$

88. See generally Eric Talley, Corporate Inversions and the Unbundling of Regulatory Competition, 101 VA. L. REV. 1649, 1681 (2015) (noting that between 1994 and 2004, 22 inversions were announced, but between 2004 and 2014, 49 inversions were announced, 20 of which were announced in or after 2012).

89. Berle viewed national borders as having already lost their logical relevance to economic regulation by the 1950s. See Basic Elements, supra note 11, at 429 ("A second supranational community was proposed by the United States: EURATOM. Now the European nations have formed 'Euromarket' (the European Economic Community), which is just getting under way. What is happening is a slow striation of political sovereignty. Each of these new organizations - and they themselves are already grouping into a single European complex - does take away some fragment of power from the constituent nations, but gives each access to a wider and more balanced complex of supply and need. This is frank recognition that modern economic processes have little to do with historical, ethnic or even political boundaries, and cannot be imprisoned within them if populations are to live acceptably. Many other groupings are in progress."); see also NATURAL SELECTION OF POLITICAL FORCES, supra note 11, at 17 (noting that political forces should assign responsibility to correspond to the level of concentrated power).

90. Martin Luther King, Jr., Sermon at Temple Israel of Hollywood (Feb. 26, 1965).

91. NATURAL SELECTION OF POLITICAL ForCeS, supra note 11, at 17.

92. Id. 
He touted the advantages that the West's form of managed capitalism had for working people over those of the communist system, arguing that "[t]oday the conception of more or less equal opportunity and economic participation - the attractive heart of the original Communist ideologyis far better expressed in Scandinavia or the United States than in Russia itself, judging by results." 93

Berle was an ardent believer in the advantages of democracy, not just for the U.S., but the world:

The standards we have here studied, seem to predetermine the choice of thinking men. The ideal of free democracy excludes none; includes all. It does not invoke hatred, or master races, or divide the peoples and countries of the earth into higher and lesser forms of life. It condemns no class to destruction. Most of all, it recognizes every man and woman as an individual having worth and dignity. ... The emotions to which democracy appeals are those of brotherhood, mutual help, tolerance, and kindness. One would like to think of them as akin to universal love, were that ideal attainable by any political force.

So, it seems, as in other centuries, a world choice is again compelled - and again possible. The travail is great. The opportunity is greater still. If selection now is made well, our children may enjoy a plateau of kindly peace enduring longer, intellectually more fertile, spiritually more serene, than any history has yet known. Multitudes are in the valley of decision, but, in the words of Joel, the day of the Lord is near in the valley of decision. ${ }^{94}$

Given his values, one can venture with some confidence that Berle would have viewed with disdain the nativist arguments made by President Trump, the UK Independence Party in Great Britain, the National Front in France, and similar parties to exploit the economic insecurities of the American and European working and middle classes. Although Berle would have understood why those directly affected by dislocation would be tempted by those arguments, ${ }^{95}$ no doubt he would have found it

93. Id. at 68.

94. Id. at 99

95. In his writings, Berle argued for the need for a value-based plan to address economic insecurity, in part because that insecurity was being exploited by fascists and other unsavory elements. See, e.g., Adolf A. Berle, Jr., We Are Looking Down the Gunbarrels, 3 VITAL SPEECHES OF THE DAY 655, 656 (1937) [hereinafter We Are Looking Down the Gunbarrels] ("If a country must exchange with other countries to live, and if business is interested in peace - then business must arrange to effect the exchange. Otherwise it must recognize that it cannot meet its function in a modern world, and must abandon the field to the Communists and the Fascists, who are now asserting that private business has become merely predatory: and that the State must take over all functions. We might as well use blunt language today. Wherever business cannot meet economic need, the totalitarian state moves in."); Adolf A. Berle, Jr., Bread and Guns, 47 SuRveY 269 (1921) [hereinafter Bread and Guns] ("No 
dismaying to have demagogues gain traction by arguing that slamming the doors on immigrants and international trade would magically cure their problems. ${ }^{96}$ But realist that he was, he would not be surprised when those demagogues were facing off with Davos Democrats, rather than descendants of FDR willing to give full-throated voice to the need to address the legitimate demands for economic security and more economic equality coming from working people in the U.S. and EU. ${ }^{97}$ Fear when unaddressed is a powerful motivator, ${ }^{98}$ and the absence of countervailing hope for real action leaves a void for negativity that would have been all too familiar to Berle.

American farmer or laborer, left to himself, would voluntarily shoot or be shot at by a Japanese peasant. The Japanese thinks the same. Fighting is the last thing he wants to do. Until each has been hypnotized by propaganda or chicane into believing that the other strains to bring fire and destruction into his country, either would make a friend of the other should they chance to meet.... They will fight any one if they have to; they do not want to fight at all. But interpose the machinery of government; let it start its propaganda, focusing national attention on preserving some point of honor or some avenue of trade - let it set up the doctrine of 'interests abroad' - and war looms first as a disagreeable possibility, then as a matter of necessary defense, and at last blooms forth as a sacred duty to purify the world. Yet after the war is over and the tale is told the fighter's table is less well set than he had never fought and usually the whole issue of the thing would not have made a penny's difference to ninety-five out of every hundred million people in the warring countries, whatever the outcome.").

96. See generally RODRIK, supra note 49, at 172 ("Right-wing media outlets and think tanks have spun tales that led voters with stagnating incomes to attribute their hardship to minoritiesAfrican Americans, immigrants, women on welfare-that the government has supposedly favored over them. As a result, conservatives have been able to retain power despite their pursuit of economic and social policies that are inimical to the interests of the middle and lower classes."); Drawbridges $U p$, ECONOMIST (July 30, 2016), https://www.economist.com/news/briefing/21702748-new-dividerich-countries-not-between-left-and-right-between-open-and [https://perma.cc/6VB9-LASM] (noting that "drawbridge-uppers," those politically aligned by their support for a closed nation, their "suspicion of trade and immigration," and disdain for "their country's elite, whom they invariably describe as self-serving," "are firmly in charge" in Poland and Hungary, "in France Marine Le Pen, who thinks that the opposite of 'globalist' is 'patriot', will probably make it to the run-off in next year's presidential election. In cuddly, caring Sweden the nationalist Sweden Democrats topped polls earlier this year, spurring mainstream parties to get tougher on asylum-seekers. Even in Germany some fear immigration may break the generous safety net. 'You can only build a welfare state in your own country,' says Sahra Wagenknecht, a leader of the Left, a left-wing party.”).

97. In an interesting study of post-war developments in addressing poverty and inequality, Professor Samuel Moyn argues that approaches to economics that address only the alleviation of poverty, and not the need to constrain immense inequality, are themselves insufficient. As he notes, FDR focused on both alleviating poverty and reducing inequality, and advocated taxation and other policies designed to make sure that the rich contributed to increasing economic opportunities for the many. Samuel Moyn, Not Enough: Human Rights in an Unequal Time 68-88 (2018). As Professor Moyn notes, these policies required the sort of muscular governance that Berle stood for:

In the alternative tradition of welfare combining the aims of sufficiency and equality, . . a

strong state - built with interventionist capacities, funded by high taxes, and able to call

forth the zeal of its people - served as the equalizing power. Equality was never achieved

by stigmatizing governance but instead by enthusiasm for it and even devotion to it. Id. at $218-19$.

98. See generally id. (describing that "[n]early all drawbridge-up parties argue that their country is in crisis, and explain it with a simple, frightening story involving outsiders"). 
V.

From these building blocks, one can see emerge the framework that might form the basis for a Berle-backed plan for a global New Deal, based not on expanding trade within a pre-New Deal laissez-faire formulation, but on ensuring that the protections working people had gained through the New Deal and European social democracy were preserved and expanded to the full scope of the international economy. ${ }^{99}$ That framework would focus on objectives that could be universalized and that involved widely shared understandings of fundamental economic rights. It would recognize the inevitability that markets and large corporations will, and largely already have, outgrown the ability of individual nations to regulate. The framework would also take into account the compelling scientific case for urgent global action to address climate change, and the compelling economic case that doing so can help increase the economic security of working people affected by globalization and scientific advancements.

As a realist, Berle would also likely see value in steps that could be taken locally and by way of non-government organizations, at a time when the possibility of progress by national governments in isolation, much less in concert, is hampered by nativist impulses on the right and the timidity of Davos Democrats on the left. ${ }^{100}$ Sensible local measures could, like the

99. Reshaping the American Economy, supra note 6, at 219 ("Federal responsibility for the functioning of the American economy is taken for granted. Disbelief if not outright denial is encountered when the hands-off, night-watch man, laissez-faire theory of federal government, obtaining until his era, is set out. In current context, it is hard even to imagine the possibility of having an economy without federal management of currency and credit, without federal policing of securities issues and the stock market, without minimum wage laws and social security, without a National Labor Relations Act, without an agricultural stabilization program, perhaps even without federal management of electricity, certainly without the highly articulated statistical services in whose development Roosevelt was so vividly interested. No one thinks of housing without the credit facilities offered through the Federal Housing Authority or conceives that the capital supply of the country could be cut off (as was attempted in 1934) merely because investment bankers decided not to offer securities to the public in protest against passing the Securities Act.").

100. The tensions that economic insecurity can produce on the left are well illustrated by the rise of a right wing political party in Italy headed by a comedian: the "Five Star Movement." An incisive essay describes the agenda of this party in terms that make these tensions all too evident. Alexander Stille, Not So Funny, N.Y. REV., May 10, 2018, at 40 ("The FSM is another expression of the populist wave that has swept so many Western democracies in the past several years. It has a loud, foulmouthed, and charismatic leader who dares to say what others only think; it makes innovative use of digital technology and social media; it advocates economic protectionism; it stokes anti-immigrant sentiment, violent anger at the traditional press, and skepticism of established experts and professional politicians. And it has a soft spot for Vladimir Putin. The FSM also draws on left-wing populist ideas: a guaranteed minimum income, environmentalism, and a deep distrust of global capitalism. It has developed new forms of political participation and expressed a strong idealistic desire to clean up politics, limit the power of professionalism politicians, and use the Internet to make politics more responsive to ordinary citizens. How a blog started by a stand-up comic has become the largest party in one of Europe's largest countries is worth serious attention, both for what it portends for Italy and for what it suggests about our time."). 
steps taken in individual American states before FDR took office as President ${ }^{101}$ help some hurting people right now and provide a basis for later national and international action. ${ }^{102}$ But, for that very reason, Berle would wish there to be a focus on areas of wide agreement and potentially large impact, so that these local initiatives could eventually converge into global norms, and ultimately laws as binding as those that protect access to markets. ${ }^{103}$

One area where I suspect that Berle would not join in full-throated Trump bashing is in the President's willingness to consider using negotiations over tariffs and other terms of trade to protect legitimate American interests and, even more important, to ensure that the key protections for working people are not eroded by allowing nations and corporations that put their foots on the necks of workers and that despoil the environment free access to the markets of nations committed to the values of the New Deal and social democracy. ${ }^{104}$ Precisely because Berle

101. FDR4FREEDOMS, BECOMING A LEADER: FDR BEFORE THE PRESIDENCY 6 (observing that FDR's initiatives, as Governor, including his creation of the Temporary Emergency Relief Administration, which made New York the first state to have its own agency to coordinate relief for unemployment and impoverishment, support for unemployment insurance, and advocacy for a federal old-age insurance program, "were forerunners of the New Deal FDR would advance on a national scale as president"); see also Franklin D. Roosevelt, Discussion of 1930 Legislative Session-First Report to the People (Apr. 16, 1930) (summarizing the achievements of the 1930 legislative session in addressing such issues as infrastructure, job creation, poverty, financial regulation, parole reform, and farmers' economic stress).

102. See also Bruce Katz, Why Cities and Metros Must Lead in Trump's America, BrooKINGS InST. (Nov. 21, 2016), https://www.brookings.edu/research/why-cities-and-metros-must-lead-intrumps-america/ [https://perma.cc/8PZ7-9MUT] (suggesting that U.S. metropolitan areas, which "house 84 percent of our population and generate 91 percent of our GDP" will need to proactively engage with the federal government to secure support for social and economic concerns, but will also need to "raise substantial capital on their own to make meaningful and durable contributions to innovation, infrastructure, human capital, children, and quality places in their communities" through "metropolitan financing," which involves "new financial instruments and practices [that] have the potential to channel private and civic capital toward a number of nontraditional activities, like inclusivity and environmental sustainability," "new intermediaries ... emerging to bring disparate sectors of society together," and "new breeds of special-purpose public, quasi-public, and civic institutions [that] are forming to unlock the value of underutilized public assets and finance a wide range of transformative projects") (emphasis omitted).

103. Adolf A. Berle, Jr., Both Dreamers and Diplomats Are Needed, 10 VITAL SPEECHES OF THE DAY 150, 151-52 (1943) ("The vast problem of securing a reconstituted world system which can maintain peace and recognize human rights can only be carried forward by finding and increasing a common denominator of public opinion."); Basic Elements, supra note 11, at 433 ("It is evident that the stalemate can only be broken by some entirely new picture of world organization, corresponding to the realities imposed by the deep forces I have mentioned. So the time has again come for global thinking.").

104. One of the most distinguished scholars studying the effect of globalizing trade is, like Berle was, a pragmatist. In his most recent work, Professor Dani Rodrik explains why he views it as advisable to not adopt purist, free market principles as a basis for trade agreements in a world where none of the counterparties in fact act on a pure, free market basis. See generally RODRIK, supra note 49. 
was a realist, he would know that associating the word "free" in any way with China is Orwellian, ${ }^{105}$ and that most of our economic competitors use mercantilist tactics to advantage their own industries. ${ }^{106}$ Berle would not hesitate to have the United States engage on these issues, but his spirit

105. Robert Kuttner, Trump: The Bull in the China (Policy) Shop, AM. РRospect (Mar. 6, 2018), http://prospect.org/article/trump-bull-china-policy-shop [https://perma.cc/B729-JJCB] ("Beijing subsidizes production, floods the world with a glut of products at prices below their true costs, blocks imports, demands trade deals with western 'partners' on terms that transfer technology and leadership to China, uses state intelligence agencies to steal intellectual property whose transfer it can't coerceand then demands and gets special treatment under the WTO as a developing country! All of this grossly violates free-market norms, and grabs market share in industry after industry at the expense of nations like the U.S. that mostly play by the rules. . . Raising tariffs on state-subsidized steel and aluminum is a good and necessary part of the right policy. Trump's version, so far, has energized his critics and united America's adversaries. It's time for the mainstream to take back the challenge of how to deal with China. Otherwise, we leave the field to Trump."); Clyde Prestowitz, China's Not Breaking the Rules. It's Playing by a Different Game, ForEIGN POL'Y (Feb. 17, 2012), http:// foreignpolicy.com/2012/02/17/chinas-not-breaking-the-rules-its-playing-a-different-game/ [https:// perma.cc/DW9G-6NLX] ("The global economy is, in fact, sharply divided between those who are playing the free trade game and those who are playing some form of mercantilism.... It's like watching tennis players trying to play a game with football players. It doesn't work, and insisting on playing by the rules doesn't help, because both sets of teams are playing by the rules of their game. In any case, there are a lot fewer clear cut rules than most people think. For example, probably the biggest single factor in the off-shoring of large chunks of U.S. based production and millions of jobs abroad has been the packages of financial investment incentives offered by China and others to global companies to encourage them to relocate production. More jobs have been lost to these packages than to currency manipulation. But you can't complain about rules violations because there are no rules to cover these investment incentives. At the federal level, America[] doesn't offer such incentives but there is not [a] WTO or IMF or other rule against it. Nor is the United States proposing any rules in this area."); Robert L. Kuttner, Development, Globalization, and Law, 26 MiCH. J. INT'L L. 19, 28 (2004) ("[T]he most successful economies of the post war era have been precisely those, mainly in Asia, that combined a fierce entrepreneurial skill with a strong developmental role for the state; a combination of capitalism and neo-mercantilism. It is bizarre that champions of laissez-faire economics claim China's ten percent annual growth rate as evidence for their side of the argument. This is a nation, after all, that pegs its currency, has neither transparent capital markets nor western style human rights, whose industry and banking system is still dominated by the state, and who allows in foreign investment only on carefully negotiated terms.").

106. The case of China raises another realist challenge Berle would easily grasp: when a participant in international trade has non-market objectives for sponsoring corporate involvement in the market - such as the capture of technology and resources to gain military muscle and strategic influence rather than profits - should that participant benefit from the rules of the game, the principles which it does not accept? Distinguished scholars associated with Berle's beloved Columbia have issued a provocative proposal as to how this question might be more effectively and fairly addressed through multilateral action by the OECD. See Jeffrey N. Gordon \& Curtis J. Milhaupt, China as a "National Strategic Buyer": Towards a Multilateral Regime for Cross-Border M\&A (European Corp. Governance Inst., Working Paper No. 407, 2018); see also RODRIK, supra note 49, at 29, 134-35 (explaining that China has sought access to trade agreements designed around economic principles, such as a largely private sector approach to business, that its mercantilist policies do not accept, and that China is a repressive regime that approaches economics as an adjunct to its larger national ambitions). 
would be different than Trump's. ${ }^{107}$ Rather than pursue goals in isolation, Berle would seek to have the United States build alliances that would make fair treatment of workers, proper regard for the environment, and other widely shared principles of the New Deal central to trade agreements. ${ }^{108}$ Throughout his career, Berle believed that it was critical to promoting a peaceful world that the United States and business elites help facilitate more international commerce. ${ }^{109}$

Berle's writings suggest that he would want the United States to solidify its trade relations with the EU, the broader OECD, and other nations committed to social democracy, and to use that base as the foundation for a growing world framework that made protection for workers and the planet as important as protection for capital and product

107. For example, in a 1937 speech, Berle characteristically took a practical approach, whereby he argued for lowering tariff barriers but in a manner that took into account the legitimate interests of those negatively affected:

Good national and international business would suggest wiping out the tariff, giving the foreign importer free play. This would disturb an American group of producers and labor. Well, suppose it does. Who is hurt, and how much? What will it cost to compensate the people who are asked to retire from the field? In some cases, a small tariff for a short time, devoted to readjustment wages, for the displaced labor and readjustment costs for the displaced plant would save money for everyone all around.

We Are Looking Down the Gunbarrels, supra note 95, at 656; see also Other Forces Which Determine Our Foreign Policy, supra note 78 (making a similar argument).

108. Professor Wang's excellent article in this symposium does a thorough job of showing Berle's career-long commitment to building a system of international relations, including those affecting the economy, that would promote not only peace, but economic security, on a win-win, not zero-sum, basis. See generally Jessica Wang, Looking Forward in a Failing World: Adolf A. Berle, $J r$, the United States, and Global Order in the Interwar Years, 42 SEATTLE U. L. REV. 385 (2019). Some of Berle's writings making this point include Peace Without Empire, supra note 13; Welfare of the Masses, supra note 7; and Adolf A. Berle, Jr., The Economic Interests of the United States in InterAmerican Relations, 4 DEP'T ST. BULL. 756, 757 (1941).

109. In fact, before World War II, Berle wrote a series of articles linking economic cooperation to the avoidance of, and later to winning, the war against fascism. E.g., We Are Looking Down the Gunbarrels, supra note 95, at 655 ("We have learnt that a major cause of war is economic distress, especially the distress of overpopulated countries seeking necessary supplies for their peoples. To have these supplies they must be able to pay; to pay they must be able to sell; to have markets for their own products. ... A great, self-contained nation like our own, can insist, for a short time, that the problem is mainly one for foreigners; that we can worry along without selling farm products and certain manufactures abroad; that we are better off by rigidly excluding virtually all foreign goods from our markets. But it is well to look at the other side of the picture. . . Certain of the major central European powers, and Japan, must import merely to eat. If, in addition, they wish to develop a high standard of living, they must import still more. To do this they must export. If commerce fails, there is only one resource left - that of conquest. ... It is the job of American business not to work out new methods of embargo disguised as tariffs or sanitary regulations to keep out goods, but to work out ways and means by which goods can be let in. ... Every tariff bill has a bayonet wrapped up in it."); id. ("It is the job of American business not to work out new methods of embargo disguised as tariffs or sanitary regulations to keep out goods, but to work out ways by which goods can be let in."); see also Bread and Guns, supra note 95; Other Forces Which Determine Our Foreign Policy, supra note 78; Adolf A. Berle, Jr., Relations Between the Two Americas, 5 VitAL SPEECHES OF THE DAY 149 (1938). 
flows. ${ }^{110}$ In other words, he would be aggressively internationalist, but insist on moving toward the values upon which the post-World War II international economic order were originally to be based, values that made the interests of working people and full employment central to understandings about opening markets to international trade. ${ }^{111}$

What might the basis for such an agenda consist of? I will sketch out just some of what could be the key elements.

I start with workers. An international movement to make sure effective minimum wage legislation was a condition of being a participant in international markets would surely be a sensible Berlean agenda item. ${ }^{12}$

110. A good example of Berle's understanding of the complexity, but necessity, of forging international economic understandings is his call for "Peace Without Empire," which focused on the nations of the Americas. Peace Without Empire, supra note 13, at 108; see also The Soviet-Chinese Complex, supra note 12, at 67-68 ("This is not the time or the place to elaborate the emerging principles of what seems to be the order demanded by the second half our century. Enough to say that each country must apparently be intensely nationalist in preserving certain values assumed by it to be crucial - as in the United States the fostering and developing of individuality and of the unfettered minds and souls of free men appears to be a value without which life itself means little. To maintain its power and right to preserve these values a nation must, it seems, join at least in regional combinations. ... [I] f there is ever to be a world at peace, a nucleus of world organization capable of becoming in time custodian of peace and administrator of a degree of law must be built and fostered and maintained - and for this reason if the United Nations were to dissolve tomorrow the world would have to reinvent it.").

111. The Coming Epoch, supra note 10, at 614 ("The foundation of society, national and international, must lie in the satisfaction of the elementary desires of hundreds of millions of men who want to make a life for themselves, and, while making it, to be free of fear of sudden conquest, free of fear of oppression in thought or spirit, and free of the fear of being tossed onto a scrap heap by military or economic processes over which they have no control."). In that same article, Berle said that after the emergency of World War II was over, "we shall face the titanic task of turning tens of millions of men from the work of defense and of war into the work of peaceful life," and that:

[W] shall also wish to do this not only for ourselves, but for other like-minded peoples as well. The food and products of the Americas will be urgently needed in many parts of the world. We on our side will need materials and other products if we are to rebuild on a scale equal to the new conceptions of life. We shall have to fit our work into that of other nations as widely as may be possible. We may have to begin on a relief basis, as happened in 1920; but it must evolve into a more solid and permanent system of mutual exchange of benefits as the new and broader international basis is established.

Id.

112. Property, Production and Revolution, supra note 9, at 9-10 ("A second line of development impinges directly on management operation. It arises from an evolving social concept of what American civilization should look like. It began with the minimum wage legislation and the Wagner Act, later revised by the Taft-Hartley Act and modified by the Landrum-Griffin Act. These statutes, and the growing body of case and administrative law under them, limit the decision-making power of corporate managements with respect to wages and labor relations. Of interest is the fact that these laws in the main (though not universally) are applied to general enterprise for profit-making operations in production or commerce."). An interesting new study by the United Way illustrates the utility of a focus on a living wage. In its "ALICE Project," the United Way sought to identify how many households that, although being above the federal poverty line, do not earn "enough to afford basic necessities." UNITED WAy, ALICE STUdy OF FINANCIAL HARDShIP 1 (2016). ALICE stands for "Asset Limited, Income Constrained, Employed," and involves households above the poverty line "but with not enough to live and work in the modern economy." Id. In the thirteen states that participated, 
Developing an international movement that would perhaps focus on a tiered system of four or so "living wage" targets, appropriate to various segments of the world economy, but in all cases providing more leverage to working people and diminishing the potential for exploitation, ${ }^{113}$ would involve a push for progress that would have almost consensus international support. ${ }^{114}$ So too would requirements for safe working conditions, a strong ban on child labor, increased requirements for children to attend school, and limits on working hours. ${ }^{115}$ And yes, it would involve restoring and revitalizing the ability of workers in the U.S. to join together in unions and bargain for better pay and working conditions. ${ }^{116}$

at least $31 \%$ of households were in this category in even the most prosperous of the states, and more than half of jobs in every surveyed state other than Connecticut paid less than $\$ 20$ per hour. $I d$. at 34. Putting a point on Berle's emphasis on economic security, $72 \%$ to $84 \%$ of families in surveyed states lacked any saving to address a loss of unemployment, an unexpected medical, home, or auto expense, or other adverse development. Id. at 4 . This is especially concerning given the fact that less than a fourth of unemployed workers receive unemployment insurance. Will Kimball, Unemployment Insurance Benefits Reaching a Smaller Share of Unemployed Workers, ECON. POL'Y INST. (Mar. 18, 2015), https://www.epi.org/publication/unemployment-insurance-benefits-reaching-a-smaller-shareof-unemployed-workers/ [https://perma.cc/S49Z-QZQH]. Consistent with data suggesting that the recovery from the Great Recession has been uneven, the study showed that the percentage of ALICE households in each surveyed state had grown from 2007 to 2014. UNITED WAY, ALICE STUDY OF FINANCIAL HARDSHIP 5 (2016).

113. See generally Pankaj Ghemawat, People Are Angry About Globalization. Here's What to Do About It, HARV. BuS. REV. (Nov. 4, 2016), https://hbr.org/2016/11/people-are-angry-aboutglobalization-heres-what-to-do-about-it ("According to a recent IMF report, technological progress and the decline of unions have both contributed to the increase in inequality, with globalization playing a smaller but reinforcing role.... If the Netherlands can preserve a relatively reasonable income distribution despite having a trade-to-GDP ratio six times that of the U.S., it seems implausible to blame the much higher level of inequality in the U.S. economy on globalization. But not all analysts agree on this point. ... Attending to inequality is arguably more politically palatable now, given the sharp increases in inequality and a better understanding of its social costs-including possibly triggering a more populist-protectionistic-xenophobic phase.").

114. COUNCIL ON FOREIGN RELATIONS, supra note 47, at 34 (reporting the results of a poll of seventeen countries indicating that, on average, $81 \%$ of respondents, $93 \%$ of respondents from the United States, and $95 \%$ of respondents from Great Britain think that parties to international trade agreements should be required to maintain minimum standards for working conditions).

115. A general consensus exists in the West that humans cannot live a good life without an active role for government in ensuring their freedom from, among other things, working a 70-hour work week, being employed as a child, laboring under unsafe conditions, breathing air and drinking water polluted by manufacturing concerns, suffering injuries from unsafe products, and providing for themselves in their golden years without any societal help. For example, the Charter of Fundamental Rights of the European Union includes protections on the topics of maximum working hours, child labor, workplace safety, environmental concerns, consumer protection, social security and social assistance. Charter of Fundamental Rights of the European Union arts. 31-32, 34-38, 2000 O.J. (C 364) $15-17$.

116. As a general matter, it appears that younger Americans have a much more positive view of unions. Harold Meyerson, What Now for Unions?, AM. PROSPECT (Mar. 26, 2018), http://prospect. org/article/what-now-unions [https://perma.cc/GAF7-XN6B] (citing poll data that 76\% of Americans under 30 approve of unions and that $75 \%$ of new union members in 2017 were under 35); see also AFL-CIO, WORKING FOR OUR FUTURE: POLICIES FOR A NEW GENERATION OF WORK 7 (2017), https://aflcio.org/sites/default/files/2017-03/Working\%2BFor\%2BOur\%2BFuture\%2BPlatform _ 
It would also require a commitment to moving toward a system for health care that made sure that workers had health security that was not tied to employment with any particular employer, a move that would reduce the disincentive for corporations to employ American workers and reduce the anxiety felt by employees who are lectured to recognize the reality that they will change jobs many times in a dynamic economy, but who face losing access to health care when they do so. ${ }^{117}$

Finally, long term, it would involve embedding the protections for working people in the international regimes dealing with trade, as was originally envisioned by FDR and others planning the post-WWII world. A constant, unrelenting insistence that the protection of workers should be fundamental to all trade understandings, made a duty of the WTO to

final.pdf ("The union premium is highest for younger workers. For 16- to 24-year-olds, union membership means 21.75 percent higher wages, and for 25- to 34-year- olds, a union card means 19.19 percent more pay.").

117. Because health insurance in the United States remains predominantly tied to employment, employers have an incentive to locate jobs elsewhere and employees can be resistant to transitioning jobs because of health care insecurity. AARP, JOB LOCK AND EMPLOYER-PROVIDED HEALTH INSURANCE: EVIDENCE FROM THE LITERATURE 1 (2015), https://www.aarp.org/content/dam/aarp/ppi/ 2015-03/JobLock-Report.pdf [https://perma.cc/DZ7E-DZRT] ("The need for health insurance can affect a worker's decision to look for a new job, start a business, retire, or temporarily leave paid employment to care for a young child or a frail family member. Not being able to find another job that provides health insurance or to afford insurance in the individual market may lead workers to stay at a job even when it is a poor fit. ... The likely range of a job-lock effect is a reduction in turnoverthe rate at which people leave jobs - of 15-25 percent among workers with [employer-provided health insurance]."); Erik Holm, Buffett: 'Medical Costs Are the Tapeworm of American Economic Competitiveness', WALL ST. J. (May 6, 2017), https://www.wsj.com/livecoverage/berkshirehathaway-2017-annual-meeting-analysis [https://perma.cc/SX3U-FLVE] (describing how Warren Buffett "mock[ed] corporate executives who complain about taxes, saying they all know that health care costs are the real issue," at Berkshire Hathaway's 2017 annual meeting and quoting Buffett as saying: "Medical costs are the tapeworm of American economic competitiveness"); Toni Johnson, Healthcare Costs and U.S. Competitiveness, COUNS. ON FOREIGN REL. (Mar. 26, 2012), https://www.cfr.org/backgrounder/healthcare-costs-and-us-competitiveness [https://perma.cc/8MQ3N556] ("For large multinational corporations, footing healthcare costs presents an enormous expense. General Motors, for instance, covers more than 1.1 million employees and former employees, and the company says it spends roughly $\$ 5$ billion on healthcare expenses annually. GM says healthcare costs add between $\$ 1,500$ and $\$ 2,000$ to the sticker price of every automobile it makes."). See generally U.S. CENSUS BurEAU, HEALTH INSURANCE COVERAGE IN THE UNITED STATES 1 (2015), https://www.census.gov/content/dam/Census/library/publications/ 2016/demo/p60-257.pdf (55.7\% of Americans had employer-based health insurance in 2015); Press Release, Bureau of Labor Statistics, Employer Costs for Employee Compensation (June 8, 2018), https:/www.bls.gov/news.release/ecec.nr0.htm [https://perma.cc/LVB3-V8QL] (on average, health insurance benefits make up $7.5 \%$ of total compensation for workers in private industry). Berle was also concerned about this issue. See, e.g., The Quest for Individual Security, supra note 7, at 407 (describing "the problem of sickness and health insurance" as a "major problem of personal security" that needs to be addressed "by some cooperative method throughout the community"); id. (focusing on the analogous problem of how workers could change jobs and not lose the credit they have earned towards their pensions). 
enforce, and not relegated to weaker organizations like the ILO, ${ }^{118}$ would be Berlean and timely. ${ }^{119}$

Likewise, a Berle-infused agenda would focus on providing retraining and transition assistance to workers needing to change careers or find new jobs. ${ }^{120}$ U.S. investment in this area has lagged for years, being given lip service but no funding. ${ }^{121}$ Berle recognized the need for

118. See generally Brown, supra note 49, at 108 ("Labor rights activists nevertheless argue in favor of some link between the ILO and the WTO on labor issues in order to provide the ILO with enforcement power beyond its current practice of monitoring and providing members with advice and technical support.... While the ILO may be effective in promoting discussion between workers and member governments, it has none of the remedies available to members of the WTO. For this reason, linkage between the ILO and the WTO has been suggested as a way of transferring some enforcement power on trade policy to labor standards.").

119. In a speech in 1935, Berle distanced himself from those whose interest in trade questions dealt with whether their business would increase or decrease depending on tariffs and other barriers, associating himself instead with those who viewed themselves as members of a common international family of human beings. Other Forces Which Determine Our Foreign Policy, supra note 78, at 416 ("We know something of the great glory of a common intellectual heritage. We have shared the aesthetic fertility of many countries. We have no truck with second-grade hatreds. Many of us have friends in all countries and propose to have more. Our job is to study to see whether new ground cannot be found."). In that speech, he also indicated his view that "where our manufacturers have succeeded, it was due not to a tariff monopoly but to the peculiar efficiency of American products." Id. He then put his finger directly on the problem that endures to this day:

We shall find that the basis of that problem was really a question of whether labor competed with labor, that is to say, whether international competition came to be competition in standards of living. Then we would begin to grapple with the real problem which is a desire not for tariffs which rise and change price levels, but for common agreements which would make for human standards of living throughout the world.

Id. (emphasis added); see also Welfare of the Masses, supra note 7 (arguing that the "inter-American group of nations" must ensure that workmen receive "a fair share through wages and social insurance"). See generally Adolf A. Berle, Jr., The Construction of a General International Organization, 10 DEP'T ST. BULL. 97 (1944) (arguing that the creation of a post-war international organization to govern security and economic issues was vital to creating the conditions for a lasting peace and stable world order).

120. The Law and the Social Revolution, supra note 73, at 594 (arguing that, to "distribut[e] income when the labor of an individual is not needed," we must "redefin[e] the rights and the status of individuals in terms of economics - just as we redefine personal rights and status in terms of civil and political privileges in the Declaration of Rights in the United States Constitution. The law will have to be built upon this redefinition, the mechanics of which might be, for example, enrolling all able-bodied individuals into a labor reserve, providing for their necessities, their sickness and unemployment insurance, differentiating their wages so that the married man with a family receives enough to support the family instead of being placed on a dead equality with the bachelor, and so that women performing equal tasks receive an equal income - an income enlarged when, as is usually the case, the woman helps in supporting her family"). See generally Government Function, supra note 7, at $32-33$.

121. RODRIK, supra note 49, at 205 (discussing how "trade adjustment assistance" was cut during the Regan era despite the United States "open[ing] itself up to imports from Mexico, China, and other developing nations more extensively"); see also Mark Muro \& Joseph Parilla, Maladjusted: It's Time to Reimagine Economic 'Adjustment' Programs, BrooKINGS INST. (Jan. 10, 2017), https://www. brookings.edu/blog/the-avenue/2017/01/10/maladjusted-its-time-to-reimagine-economic-adjustmentprograms/ [https://perma.cc/3BRK-S5MY] (showing that the United States spent less $(0.11$ percent of GDP) on active labor market adjustment programs in 2014 than Japan (0.17 percent), Canada (0.22 
transitional assistance of this kind. ${ }^{122}$ Similarly, his focus on the value of education is relevant here, ${ }^{123}$ as much of the economic insecurity has been felt among people with the least education. Widening the availability of relevant training and educational opportunities relevant to succeeding in the evolving economy is also something of universal appeal. ${ }^{124}$

Government investment to create jobs and, while doing so, build skills, would be an obvious Berle move, ${ }^{125}$ as you cannot transition workers to new and better jobs if they do not exist. ${ }^{126}$ Addressing the huge

percent), Korea (0.45 percent), Germany (0.66 percent), or France (0.99 percent)); Why They're Wrong, ECONOMIST (Oct. 1, 2016), https://www.economist.com/news/leaders/21707926-globalisati ons-critics-say-it-benefits-only-elite-fact-less-open-world-would-hurt [https://perma.cc/N893-C9W5] ("America spends a paltry $0.1 \%$ of its GDP, one-sixth of the rich country average, on policies to retrain workers and help them find new jobs.”).

122. Government Function, supra note 7, at 32-33 (noting that free governments have intervened in economic operations to assist individuals entering new fields of production; provide indirect assistance, such as subsidies and temporary monopolies, to stimulate employment; provide direct financial assistance; facilitate nonpublic and nonprivate operations, such as public infrastructure; and to parallel certain operations of private enterprises to ensure continued production, even when private enterprises are unable or unwilling to continue their operations).

123. Welfare of the Masses, supra note 7, at 469 (stating that education is "the most profitable expenditure possible. Even in cold economics the returns from education are enormous"); The Quest for Individual Security, supra note 7, at 406 (arguing that "part of the problem of security . . . relates to the education of children," that no one feels secure unless their child has hopes for a better future, and that it is difficult to make college education affordable when it could cost a child...GASP...\$2,600 a year to go to Harvard!).

124. See Pew Research Ctr., The State of American Jobs (Oct. 6, 2016), http://www. pewsocialtrends.org/2016/10/06/the-state-of-american-jobs/ [https://perma.cc/FV5S-R4U3] ("More than half $(54 \%)$ of adults in the labor force say it will be essential for them to get training and develop new skills throughout their work life in order to keep up with changes in the workplace. And $35 \%$ of workers, including about three-in-ten (27\%) adults with at least a bachelor's degree, say they don't have the education and training they need to get ahead at work."); see also GALLUP, In Depth Topics A to Z: Education, http://news.gallup.com/poll/1612/education.aspx [https://perma.cc/HXM8-XAHP] (citing a 2013 poll in which 50\% of respondents stated that obtaining knowledge and skills was more important than obtaining a degree from a well-respected university for young people to succeed); CTR. FOR AM. PROGRESS, BETTER TRAINING AND BETTER JOBS 1 (2018), https://www.americanprogress. org/issues/economy/reports/2018/02/22/447115/better-training-better-jobs/ [https://perma.cc/P5ZBGDRN] ("Workers also have little ability to ensure that the training they receive will lead to a good job, as they have minimal input into most training programs and limited power to improve the quality of the jobs for which they train. Exacerbating this is the fact that a smaller share of workers are members of unions today than several decades ago. In the current economy, workers are increasingly on their own, without sufficient tools and the structures they need to succeed."). See generally Crain, supra note 25, at 95 (discussing labor policies in Scandinavia, "where governments support workers directly - through wage subsidies, retraining sabbaticals, and temporary public jobs").

125. Berle spent his short stint as an official New Dealer working in the Reconstruction Finance Administration to stimulate government works projects to jump start the economy and create needed jobs for the unemployed. See 1969 Interview with Berle, supra note 6, at 25.

126. Lawrence Mishel, Tired of Economists' Misdirection on Globalization, WoRKING ECONOMICS BLOG (Apr. 26, 2016, 12:42PM), https://www.epi.org/blog/tired-of-economists-misdire ction-on-globalization/ [https://perma.cc/3QEF-AKYX] ("You can't adjust a dislocated worker to an equivalent job if good jobs are not being created and wages for the majority are being suppressed. ... If free-traders had actually cared about the working class they could have supported a 
full range of policies to support robust wage growth: full employment, collective bargaining, high labor standards, a robust minimum wage, and so on. They could have strengthened social insurance. ... But they didn't."); Matthew Yglesias, American Airlines Gave Its Workers a Raise. Wall Street Freaked Out, Vox (Apr. 29, 2017), https://www.vox.com/new-money/2017/4/29/ 15471634/american-airlines-raise [https://perma.cc/22JQ-RS22] ("The vast majority of Americans earn a living supplying services to other Americans, so when wages don't rise we struggle to find economic opportunities.").

127. The Aspen Inst., American Prosperity Project: A NonPartisan Framework fOR LONG-TERM INVESTMENT 2 (2016), https://assets.aspeninstitute.org/content/uploads/2017/01/ American-Prosperity-Project_Policy-Framework_FINAL-1.3.17.pdf [https://perma.cc/7QRK-S7EN] ("[T]he U.S. now ranks 25th in infrastructure quality per the National Association of Manufacturers."); MCKinsey Global InSt., Bridging Global InfRastructure GaPS 4 (2016), https://www. mckinsey.com/ /media/McKinsey/Industries/Capital\%20Projects\%20and\%20Infrastructure/Our\%20 Insights/Bridging\%20global\%20infrastructure\%20gaps/Bridging-Global-Infrastructure-Gaps-Fullreport-June-2016.ashx [https://perma.cc/2XAU-GNEU] ("China spends more on economic infrastructure annually than North America and Western Europe combined[.]"); AM. SOC'Y OF CIVIL ENG'RS, 2017 INFRASTRUCTURE GRADES, https://www.infrastructurereportcard.org/wp-content/ uploads/2016/10/Grades-Chart.png (last visited Dec. 28, 2017) (grading our overall national infrastructure $\mathrm{D}+$; rails $\mathrm{B}$; ports and bridges $\mathrm{C}+$; energy $\mathrm{D}+$; aviation, dams, and roads $\mathrm{D}$; and transit D-); James McBride, The State of U.S. Infrastructure, COUNS. ON ForeIGn ReL. 6-7 (Jan. 12, 2018), https://www.cfr.org/backgrounder/state-us-infrastructure [https://perma.cc/7Y3D-L3FW] ("On average, European countries spend the equivalent of 5 percent of GDP on building and maintaining their infrastructure, while the United States spends 2.4 percent. Other countries, including Australia, Canada, France, and the United Kingdom have also developed national infrastructure frameworks that allow the central government to direct and prioritize projects in a way that the United States' more decentralized system has struggled to do."); NAT'L ASs'N OF MFRS., CATCHING UP: GREATER FoCUS NEEDED tO ACHIEVE A MORE COMPETITIVE INFRASTRUCTURE 13 (2014), http://www.nam.org/ Issues/Infrastructure/Surface-Infrastructure/Infrastructure-Full-Report-2014.pdf [https://perma.cc/ 4 Y6E-G97K] ("In current dollar terms, infrastructure investment now is about 1.5 percent of GDP compared to a peak of nearly 3 percent in the late 1960s. Public infrastructure investment is now about 1 percent of potential GDP compared to close to 2 percent at the peak, and private infrastructure investment now is about 0.5 percent of GDP compared to previous rates of close to 1 percent.").

128. Meyer, supra note 55, at 1018 ("[I]nfrastructure investments can drive economic growth by creating employment and creating the platform for further investment in businesses.") (internal citations omitted); THE ASPEN INST., supra note 127, at 2 ("Quality infrastructure creates a better business environment: it enhances safety, productivity, and quality of life for citizens; and it supports good jobs."). A failure to improve our infrastructure will impose high costs. AM. SOC'Y OF CIVIL Eng'Rs, Failure to ACt: Closing the Infrastructure InVESTMENT GaP For AMERICA'S ECONOMIC FUTURE 26 (2016), https://www.infrastructurereportcard.org/wp-content/uploads/2016/ 05/ASCE-Failure-to-Act-Report-for-Web-5.23.16.pdf [https://perma.cc/FD5V-EW98] ("If none of these infrastructure gaps are addressed, the U.S. is expected to lose nearly \$4 trillion in GDP by 2025 and $\$ 18$ trillion in GDP over the 25 year period of 2016 to 2040, averaging over $\$ 700$ billion per year. From 2016 to 2025 , each household will lose almost $\$ 3,400$ each year in disposable income due to infrastructure deficiencies; and if not addressed, the loss will grow to an average of $\$ 5,100$ annually from 2026 to 2040. From 2016 to 2025 , households will average a cumulative loss of $\$ 34,000$ in disposable income; and if infrastructure deficiencies are not addressed, households will average an additional cumulative loss of $\$ 76,000$ in discretionary income from the years 2026 to 2040. Even though net job impacts are counted in millions of jobs lost from the U.S. due to insufficient infrastructure investment, overall economic impacts in dollars lost in the economy measured by business sales and GDP will be even more dramatic than impacts on overall number of jobs. Job losses 
important, by making sure that infrastructure refurbishment is done in an environmentally responsible manner, these investments provide an opportunity for the U.S. and other nations to address climate change, and develop new technologies and industries that should create jobs. ${ }^{129}$

Berle was sensitive to all avenues by which economic power might be exploited, and to the interrelationship of them. It would not be lost on him that many of the industries that cut environmental corners also treat their workers poorly and expose them to unsafe working conditions. ${ }^{130}$ And climate change poses the greatest threat to those in the world who are the worst off. ${ }^{131}$ By embracing and spreading enforceable environmental obligations as a prerequisite to access international markets, and using pressures from both international, domestic and non-government sources (including institutional investors) to encourage means of production that are environmentally responsible, the environment and workers themselves stand to benefit. ${ }^{132}$ And again, this is an area-like support for workers'

in part will be mitigated by more people working for less money. Many of these jobs will be in replacement for technology-based and education-driven industries that are the basis of long-term economic development."); $i d$. (estimating that approximately 2.5 million jobs will be lost in the economy in 2025, and 5.8 million lost in 2040, if the failure to invest in the national infrastructure persists). For a discussion of how corporations could play a role in funding infrastructure projects to create jobs, see Peter Georgescu, Capitalists Arise 85 (2017) (suggesting that Congress encourage repatriation of corporate dollars held overseas with a low tax rate and then set those tax proceeds aside for infrastructure projects).

129. Derrick Z. Jackson, Catching a Breeze, AM. PROSPECT (Apr. 20, 2018), http://prospect.org/ article/catching-breeze [https://perma.cc/BU33-UBCE] (citing data that wind energy jobs in the US now exceed jobs in the coal industry, and citing evidence of potential for large growth in clean energy employment); Steven Greenhouse, Mobility and Social Justice: Connecting Public Transit to Great Manufacturing Jobs, AM. PROSPECT (Apr. 9, 2018), http://prospect.org/article/connecting-publictransit-great-manufacturing-jobs [https://perma.cc/CH92-5DDH] (discussing the positive effects investments in public transportation has on domestic employment in manufacturing).

130. Berle, Corporate Decision-Making and Social Control, supra note 86 at 152-53 (discussing a corporation's responsibility to the environment and workers and highlighting automobile manufacturers failings as to safety).

131. WORLD BANK GROUP, SHOCK WAVES: MANAGING THE IMPACTS OF Climate CHANGE ON POVERTY 4 (2016), https://openknowledge.worldbank.org/bitstream/handle/10986/22787/978146480 6735.pdf [https://perma.cc/TV99-U583] (“[P]oor people (i) are more often affected by the[] negative shocks or trends [associated with climate change] (they are more exposed); (ii) lose more when affected, relative to their income or wealth (they are more vulnerable); and (iii) receive less support from family, friends, and community, and have less access to financial tools or social safety nets to help prevent, prepare for, and manage impacts."); $i d$. at xi ("[C]limate change would likely spark higher agricultural prices and could threaten food security in poorer regions such as Sub Saharan Africa and South Asia. And in most countries where we have data, poor urban households are more exposed to floods than the average urban population. Climate change also will magnify many threats to health, as poor people are more susceptible to climate-related diseases such as malaria and diarrhea.").

132. A distinguished scholar argues that labor and environmental concerns have to be central to any fair approach to globalization. RODRIK, supra note 49, at 229 ("Trade experts have long been wary of opening up the WTO regime to questions about labor and environmental standards or human rights, fearing the slippery slope of protectionism. But it is becoming increasingly clear that failure to take 
rights - that has strong international support. ${ }^{133}$ To the extent that the U.S. embraces a muscular, confident approach to climate and economic change by setting aggressive targets for auto vehicle mileage and other analogous goals, the full power of American capital and ingenuity could be brought to bear for the twin purposes of tackling climate change and fueling new opportunities for American workers.

But, ugh, would Berle think we have the "Means" to accomplish these goals? As a realist, Berle would no doubt find the current political reality dispiriting, but also as presenting important pockets of opportunity.

For starters, in the long run, the connection between right wing authoritarianism and working people's economic interests is so tenuous ${ }^{134}$ that an internationalism that kept front and center the need for economic

these issues on board does greater damage."). But, he argues that instead of embedding requirements for labor and environmental standards in core trade agreements, individual nations should be permitted to impose tariffs against nations that violate fair labor and environmental standards. $I d$. at 231 ("[W]e should broaden [the fair trade concept] as it exists in trade law, to include social dumping. Just as countries can impose duties on goods that are sold below costs, they should be allowed to restrict imports that demonstrably threaten damage to domestic regulatory arrangements."). A Berlean critique might argue that part of the reason for downward pressure on wages and environmental standards has been the ability of transnational corporations to engage in regulatory arbitrage as they are able to escape regulation by flight. I believe Rodrik's argument that there should be "social dumping" is correct, but that it is essential and not inconsistent with that argument, for there to be convergence on some essential, bottom line principles that involve widely shared values, and to embed them in trade and other agreements so that businesses cannot escape compliance, and so that a firm floor is set to ensure that key values that social democrats like Rodrik embrace are not eroded.

133. Simon J. Evenett, Trade Policy: Time for a Rethink?, EURACTIV (Oct. 16, 2007), https:// www.euractiv.com/section/science-policymaking/opinion/trade-policy-time-for-a-rethink/ [https:// perma.cc/UZP5-PQHX] (discussing how Europeans have thus far failed to secure "labour and environmental standards" that they "value" through the WTO, and arguing that they be pursued instead by "alternative combinations of formal international obligations and incentives, citing budget aids as an example."); STERN SCH. OF BUS. \& N.Y. UNIV., THE INFRASTRUCTURE FINANCE CHALLENGE 28 29 (Ingo Walter ed., 2016) (noting that "[s]ustainable and green infrastructure aimed at solving environmental and social challenges is a growing priority" and observing that the UN's Sustainable Development Goals, which "covers broad objectives, such as reducing carbon and other environmental impacts, as well as support for new technologies such as electric self-driving vehicles and transportation grids in urban centers," "include criteria on clean energy, infrastructure, sustainable cities, and climate action that will require a new 21 st century approach to infrastructure"); COUNCIL ON FOREIGN RELATIONS, supra note 47, at 6 (reporting the results of a poll of seventeen countries indicating that, on average, $84 \%$ of respondents, $95 \%$ of respondents from Great Britain, and $93 \%$ of respondents from the United States think that countries that are party to an international trade agreement should be required to maintain minimum standards for protection of the environment).

134. See, e.g., Jason Margolis, Trump's Anti-Globalization Messages Resonates in 'Forgotten' Pennsylvania Town, PRI's WORLD (July 20, 2016), https://www.pri.org/stories/2016-07-20/forgottenworld-trumps-anti-globalization-message-resonates-struggling [https://perma.cc/6WDM-Y9WQ] (describing the experience of Lou Mavrakis, mayor of Monessen, Pennsylvania, a town whose population declined from 18,000 in 1960 to 7,500 in 2015 and whose major steel mill closed in the 1980 s, who feels his town has been "left behind in the age of globalization" and, as a result, despite being a lifelong Democrat governing a "Democratic bastion" where support for a Republican president was unheard of, indicated that he would "probably vote for Trump.... Whatever you can do for me, you've got my vote. If you can't do nothing for me, the hell with you. I'm telling it like it is."). 
security for working people and the middle class should have a basis for long-term success. ${ }^{135}$ That is especially so when the costs of retrenchment to working people would be huge, because many owe their jobs to international commerce as are threatened by it.

Not only that, in general, the poll data shows support for strengthened international ties and trade, ${ }^{136}$ and that support is greater among younger people. ${ }^{137}$ An internationalism that focuses on the best interests of all can build on this support, and brings back into the fold working people disenchanted with the Davos Democrat indifference to their feelings of insecurity.

Even in the wreckage of Brexit, one can see the potential for new angles of approach. Precisely because Brexit makes no sense, ${ }^{138}$ would

135. See generally Drawbridges Up, supra note 96 (finding that the success of "drawbridge-up" political parties is driven by economic dislocation, including among "mid- and less-skilled workers in rich countries [who] feel hard-pressed," and associate immigration or trade for their absence; and demographic change because although "[1]arge-scale immigration has brought cultural change that some natives welcome - ethnic food, vibrant city centres ... others find [it] unsettling ... [and] are especially likely to object if the character of their community changes very rapidly," which "does not make them racist," but lays a foundation for an "authoritarian counter-reaction" where a country experiences "historically high levels of immigration from countries with very different moralities, and without a strong and successful assimilationist programme") (internal citations omitted).

136. See COUNCIL ON FOREIGN RELATIONS, supra note 47, at 7-8 (summarizing the results of a poll that indicate that 74 percent of respondents in China, Japan, and South Korea favor a free trade agreement in the United States, and the results of another poll that indicate that on average, 67 percent of respondents in six European countries - Germany, France, Italy, Poland, Slovakia, the United Kingdom - and the United States favored a transatlantic economic initiative that would facilitate trade and investment and deepen economic ties between the United States and the European Union); $i d$. at 2 (reporting that twenty-one nations said trade's effect on their country's economy was good and finding " $[t]$ he highest levels of enthusiasm [] in Peru (92 percent), China (88 percent), Israel (88 percent), and Azerbaijan and Kenya (both 85 percent). The least enthusiasm for trade was found in Egypt (49 percent) and the United States (54 percent)."); id. (reporting that, on average, 66 percent of respondents said that trade had a good effect on companies in their country, 65 percent of respondents said it had a good effect on consumers such as themselves, and 59 percent said it had a good effect on job creation in their country).

137. See Jones, supra note 59 (reporting that among Americans, "[a]s has been the case in the past, free trade agreements are viewed far more positively by younger people than older adults. Majorities of those under $30(67 \%)$ and those ages 30 to $49(58 \%)$ say free trade agreements have been good for the country. Among those 50 and older, just $41 \%$ say free trade agreements have been a good thing. . . . By more than two-to-one ( $60 \%$ vs. $26 \%$ ), those younger than 30 say they have been helped more than hurt financially by free trade agreements. Those in older age groups are more divided in their views of the personal impact of free trade agreements."); EUR. COMM'N, supra note 59, at 23 (reporting that, among EU citizens, $69 \%$ of younger survey respondents view globalization as positive, as compared to $44 \%$ of survey respondents age 55 or older, and that $74 \%$ of student respondents consider globalization positive, as compared to $42 \%$ of retired respondents).

138. The U.K. government's inability to formulate a coherent exit strategy illustrates this, as the Tory government basically desires to continue to have what it wants from its current status as an EU member, while being able to say it left. See DEP'T FOR EXITING the EuropeAn UnION, THE United KINGDOM's EXIT FROM AND NEW PARTNERSHIP WITH THE EUROPEAN UNION, 2017, Cm. 9417, at 36 (outlining the U.K.'s priorities in negotiating a partnership with the EU that will "fulfill[] the democratic will of the people" and noting, as to the negotiations, that "[t]he focus will not be about 
there be a chance for the United States to reinvigorate the special relationship with the United Kingdom and forge trade agreements with it and the Commonwealth? Even more broadly, could the prospect of a U.S.Commonwealth-EU trade accord committing the entire bloc to full support of labor rights, environmental responsibility, and sustainable approaches to corporate governance and economic growth emerge? Although Britain is literally an island, it cannot operate as such, and the ties that Churchill called for in his famous Fulton speech to bind the English-speaking peoples will be even more important if Brexit actually ensues.

And an ironic tool has emerged. Berle would likely be dismayed at the extent to which the reemerging power of stockholders-in the form of institutional investors wielding the clout not of their own capital, but of others, largely that of working people - has fueled an erosion in corporate social responsibility, ${ }^{139}$ compromised the clout of unions and working

removing existing barriers or questioning certain protections but about ensuring new barriers do not arise"); Chris Bickerton, The Brexit Iceberg, in BREXIT AND BEYOND: RETHINKING THE FUTURES OF EUROPE 132, 136-37 (Benjamin Martill \& Uta Staiger eds., 2018) ("[T]here has been a great reluctance to accept that Brexit means the UK is 'going it alone' in any meaningful way. Nationalist histories of the past —including that of the UK - have made much of the ability to 'stand alone' but in the UK's case even confident Brexiters have sought the comfort of wider communities such as the 'Anglosphere' or the Commonwealth .... The referendum campaign itself never addressed directly the issue of the UK's status as an outsider. ... Instead, there was an extensive debate about which 'model' the UK would adopt. Critics of this discussion talked of a 'bespoke arrangement' for the UK, which had comforting echoes of receiving special treatment and of not being left out in the cold. This refusal to consider Brexit as the state transformational challenge that it is continues into the postreferendum period."); see also Laura Hughes, Conservative Party Factions Attack Theresa May's Brexit Options, Fin. TiMES (May 13, 2018), https://www.ft.com/content/120c0f18-56a7-11e8-bdb7f6677d2e1ce8 ("Under the customs partnership that Mrs[.] May favours, Britain would in theory have frictionless borders with the EU ... . The UK would mirror EU customs rules at its ports, collecting tariffs for the bloc while maintaining the right to set Britain's own duties and trade policy.").

139. Berle viewed big business as operating under a social contract. See Adolf A. Berle, Jr., $A$ New Look at Management Responsibility, 1 HUM. ResourCe MGMT. 2 (1962) [hereinafter A New Look at Management Responsibility] ("[B]ig business, in the American system, exists and derives its right to exist under, and only under, a tacit social contract. This social contract requires management of big business (let us say, arbitrarily, the 1,500 largest corporations in the United States) to assume certain responsibilities. Assumption and fulfillment of them entitles big business to the privileges it receives from the State, and to acquiescence to their existence by the economic community they affect and serve.... [T] hey are ... required, while seeking profit, to assure that their work in both these fields shall contribute to economic stability, to maintaining continuous and adequate supply, to providing continuity and stability of employment, and to providing technical advance in their industry. Seeking these results modifies, pro tanto, the old theory that the whole duty of management was satisfied by maximizing profits. Put differently, the right to make and retain profits is conditioned on working toward and, let us hope, attaining these ends."). Other writings of Berle making this point include FrEe SOCIETY, supra note 87; and Adolf A. Berle, Jr., The Duties and Obligations of American Citizenship, 10 DEP'T ST. BULl. 278 (1944). 
people in general, ${ }^{140}$ created pressures to diminish externality regulation, and contributed to the huge increase in inequality. ${ }^{141}$

But, he would also see promise in the emergence of representatives of passive, long-term investors as the key power players among stockholders. ${ }^{142}$ If these institutional investors can align their investing and

140. For example, Berle would find it astonishing to see stock market analysts react to American Airlines' decision to give its employees a raise to close the compensation gap that existed between it and its key competitors. Yglesias, supra note 126 (“'This is frustrating. Labor is being paid first again,' wrote Citi analysts Kevin Crissey in a widely circulated note. 'Shareholders get leftovers."”); id. (“"We are troubled by AAL's [American Airlines'] wealth transfer of nearly $\$ 1$ billion to its labor groups,' [JP Morgan's Jamie Baker] wrote, suggesting that the move was not just contestable as a matter of business strategy, but somehow obviously illegitimate."); see also Maureen Conway \& Mark G. Popovich, Paying Workers Better Shouldn't Be Bad News on Wall Street, ASPEN INST. BLOG (May 12, 2017), https://www.aspeninstitute.org/blog-posts/paying-workers-better-shouldnt-bad-news-wallstreet/ [https://perma.cc/CG24-73PU] ("[T]he pay increase was modest. The raises were for 5 percent to 8 percent for flight attendants and pilots respectively, and AAL offered the adjustment because salary levels had fallen behind their peers. Had they not raised salaries, AAL executives would likely have faced turnover costs. Plus, the salary increases were an affordable commitment, given the company's budget. The raises, therefore, entail a mere 0.57 percent of AAL's operating expenses, which reached $\$ 40.18$ billion in 2016. Should Wall Street analysts and investors put maximizing profits above keeping a commitment to the working people that power the enterprise?"). To have corporations subject to this sort of pressure to be callous and short-sighted undermines the social contract to others that Berle viewed as governing the exercise of corporate power.

141. E.g., Leo E. Strine, Jr., Who Bleeds When the Wolves Bite? A Flesh-and-Blood Perspective on Hedge Fund Activism and Our Strange Corporate Governance System, 126 YALE L.J. 1870, 194142 (2017) ("[P] considered yet another deepening of income inequality that reduces the wealth of the many to benefit the few.") (citing Alon Brav et al., The Real Effects of Hedge Fund Activism: Productivity, Asset Allocation, and Labor Outcomes, 28 REV. FIN. STUD. 2723, 2753 (2015) (finding that on average, workers at target firms experience stagnant wages and increased productivity, resulting in reduced productivity-adjusted wages); and citing Lawrence Mishel et al., Wage Stagnation in Nine Charts, ECON. POL’Y INST. 3 fig.1 (Jan. 6, 2015), https://www.epi.org/files/2013/wage-stagnation-in-ninecharts.pdf [https://perma.cc/Y3SP-Y94F] (showing that as of 2007, the average income of the middle $60 \%$ of American households was $\$ 17,867$ less than what it would have been had inequality not widened); John C. Coffee, Jr. et al., Activist Directors and Agency Costs: What Happens When an Activist Director Goes on the Board? 9-10 \& n.21 (Columbia Bus. Sch. Research Paper No. 18-15, 2018), https://papers.ssrn.com/sol3/papers.cfm?abstract_id=3100995 ("[S]ome evidence suggests that shareholder pressure, organized and directed by activist hedge funds, may cause the corporation to act in a more risk-accepting manner and contrary to broadly accepted public policies," for example, by "compelling some energy companies to use 'dirty' energy and shelve projects to shift to 'clean' energy”') (citations omitted); Yvan Allaire \& Francois Dauphin, The Game of 'Activist' Hedge Funds: Cui Bono?, 13 INT'L J. Disclosure GOVERNANCE 279, 290 \& fig.5 (2016) (Firms targeted by activist hedge funds saw a $2.5 \%$ decline in their number of employees while companies in the control group saw a $15 \%$ increase in their number of employees during the same time period.); see also RODRIK, supra note 49, at 209 (discussing the lack of clout labor, environmental, and other groups have to protection under trade laws as opposed to for-profit industries).

142. Lucian A. Bebchuk, Alma Cohen \& Scott Hirst, The Agency Problems of Institutional Investors, 31 J. ECON. PERS. 89, 93 (2017) (showing that for the largest U.S. corporations, the five largest institutional investors owned over $20 \%$ of the shares, and the largest 20 owned one-third); Dorothy Lund, The Case Against Passive Shareholder Voting, 43 J. CORP. L. 493 (2018) (showing that Blackrock, Vanguard and State Street—-the leading index funds-are the largest stockholders in $88 \%$ of the S\&P 500 in 2015, up from 25\% in 2000); Jill Fisch, Assaf Hamdani \& Steven Davidoff 
voting strategies with the interests of the forced capitalists whose money they hold-forced capitalists ${ }^{143}$ whose long-term wealth depends more on whether they can get and keep a good job-then that would help to reinstate the sensible framework for corporate societal accountability that Berle felt emerged from the New Deal/Social Democratic approach to capitalism. ${ }^{144}$ This framework aligns the interests of stockholders as equity investors and the interests of workers by focusing corporate goals on sustainable, responsible long-term growth, through business practices that respect societal norms and that do not externalize costs. ${ }^{145}$

Solomon, Passive Investors 1 (Apr. 13, 2018) (unpublished manuscript) (on file with author) ("Although the extent to which index funds will continue to grow remains unclear, some estimates predict that by 2024 they will hold over $50 \%$ of the market.") (citing Trevor Hunnicut, Index Funds to Surpass Active Fund Assets in the U.S. by 2024: Moody's, REUTERS (Dec. 2, 2017), https://www. reuters.com/article/us-funds-passive/index-funds-to-surpass-active-fund-assets-in-u-s-by-2024moodys-idUSKBN15H1PN [https://perma.cc/KYD3-559G]).

143. Leo E. Strine, Jr., Toward Common Sense and Common Ground? Reflections on the Shared Interests of Managers and Labor in a More Rational System of Corporate Governance, 33 J. CORP. L. 1, 4 (2007) ("“M]ost ordinary Americans have little choice but to invest in the market. They are in essence 'forced capitalists,' even though they continue to depend for their economic security on their ability to sell their labor and to have access to quality jobs.... For powerful reasons, this class of investors invests in the market primarily through intermediaries. It is these intermediaries, and not the forced capitalists, who determine how the capital of these investors is put to work and how the mountain of shares owned for their benefit is used to influence the management of public corporations.").

144. See Berle, Constitutional Limitations on Corporate Activity, supra note 9, at 937-39 (highlighting the various New Deal reforms as "solutions" that "usually reflect the end of a struggle").

145. Examples of promising efforts to have institutional investors focus on supporting corporate governance policies that promote sustainable, responsible long-term growth that is in the interests of the working people whose capital they control, include: Martin Lipton et al., The New Paradigm: A Roadmap for an Implicit Corporate Governance Partnership Between Corporations and Investors to Achieve Sustainable Long-Term Investment and Growth (Int'1 Bus. Council of the World Econ. Forum, 2016); Action Plan: Financing Sustainable Growth, EUR. PARL. DOC. (COM 52018DC0097) 8-9 (2018) ("Subject to the outcome of its impact assessment, the Commission will table a legislative proposal to clarify institutional investors' and asset managers' duties in relation to sustainability considerations by Q2 2018. The proposal will aim to (i) explicitly require institutional investors and asset managers to integrate sustainability considerations in the investment decision-making process and (ii) increase transparency, towards end-investors on how they integrate such sustainability factors in their investment decisions in particular as concerns their exposure to sustainability risks."); Annual Letter from Laurence D. Fink, Chairman, Blackrock (Feb. 1, 2016), https://www.blackrock.com/ corporate/literature/press-release/2016-larry-fink-ceo-letter.pdf [https://perma.cc/JLB2-CRLS]. See also Raj M. Desai, Homi Kharas \& Magdi AMin, Brookings Inst., COMBINING GoOd Business AND GOOD DEVELOPMENT: EVIDENCE FROM IFC OPERATIONS 4-5 (2017), https://www.brookings. edu/wp-content/uploads/2017/05/combining-good-business-development.pdf [https:/perma.cc/ L4QY-E6FX ] (observing that, at least among publicly traded companies or investment funds in the US or high-income OECD countries, ESG is being integrated into corporate operations, rather than separated into corporate social responsibility departments, supporting "a new narrative that good sustainability practices can improve the reputation of a company-as well as increase sales, enhance employee loyalty, and attract better personnel"); $i d$. ("One assessment finds that the pooled internal rate of return for investments made by 'impact' private equity funds exceeds the small-cap market index. Private equity and venture capital funds with 'impact missions' produce higher or equivalent returns as traditional funds. Meta-analyses show that social and (to a lesser extent) environmental 
Put simply, if the separation between ownership and ownership ${ }^{146}$ is addressed to make sure that institutional investors faithfully represent those whose capital they hold, the reversal of Berle's iconic separation of ownership and control can be a positive force to help make large corporations and the economy work better for the many. ${ }^{147}$

responsibility pays off. A review examining some 159 empirical analyses finds that the majority show a positive relationship between sustainability and financial performance (63 percent), while 15 percent of studies report a negative relationship, and 22 percent report a neutral or mixed relationship. A metaanalysis of over 2,000 studies shows a strong business case for ESG investments, with 90 percent of these studies finding a positive relationship between environmental sustainability and financial performance.”) (internal citations omitted); AFL-CIO OFFICE OF INV., AFL-CIO KEY VOTES SURVEY: How InVESTMENT MANAGERS VOTED IN THE 2017 PROXY SEASON 1-4 (2017), https://aflcio.org/ sites/default/files/2018-02/2017\%20AFL-CIO $\% 20$ Key\%20Votes\%20Survey $\% 20$ Report $\% 20 \% 281 \%$ 29.pdf [https://perma.cc/E4DH-N99W] (noting that the proposal selected for the survey include the categories of "increasing management accountability and advancing a worker-owner view of value," and that the AFL-CIO's Proxy Voting Guidelines support, among other measures, "measures that encourage companies to respect human and labor rights, and mechanisms aimed at promoting disclosure and sustainable business practices").

146. See Strine, supra note 143, at 6-7 ("What I mean by this is that the equity of public corporations is often owned, not by the end-user investors, but by another form of agency, a mutual fund, or other institutional investor. It is these intermediaries who vote corporate stock and apply pressure to public company operating boards. I daresay that more American stockholders own equity in Fidelity- and Vanguard-controlled mutual funds than own stock in Microsoft or GE."); Leo E. Strine, Jr., Why Excessive Risk-Taking Is Not Unexpected, N.Y. TimES DEALBOOK (Oct. 5, 2009), https://dealbook.nytimes.com/2009/10/05/dealbook-dialogue-leo-strine/ [https://perma.cc/5GNL8SGD]; Leo E. Strine, Jr., One Fundamental Corporate Governance Question We Face: Can Corporations Be Managed for the Long Term Unless Their Powerful Electorates Also Act and Think Long Term?, 66 Bus. LAw. 1 (2010); Leo E. Strine, Jr., Can We Do Better by Ordinary Investors? A Pragmatic Reaction to the Dueling Ideological Mythologists of Corporate Law, 114 COLUM. L. REV. 449 (2014); Matteo Tonello, The Separation of Ownership from Ownership, HARV. L. SCH. F. ON CORP. GOV. \& FIN. REG. (Nov. 25, 2013), https://corpgov.law.harvard.edu/2013/11/25/the-separationof-ownership-from-ownership/ [https://perma.cc/Q5FS-TNJJ].

147. Berle foresaw that workers would increasingly have their futures dependent on the growth in equity markets sufficient to fund their pensions, and that although the workers would have their money at stake, the pension fund, not they, would have the right to vote and control the stock:

The present $\$ 30$ billion in the pension trusts of course is doomed to increase. These are compulsory savings and the funds must continue to accumulate.... [I]f the pension trusts continue to take the good equities as they have been doing, they may well have the prevailing control-stockholding position and the capacity to make it absolute. They will have, say, 20 per cent to 30 per cent of the good equity stocks and the capacity to increase that to 40 per cent or 50 per cent ( 45 per cent for practical purposes is a majority at any big stockholders' meeting).

With the rise of the pension trusts into the "passive-receptive" end of the corporation structure the old "passive-receptive" stockholder is gradually disappearing. At best he is, shall we say, a pensionnaire. The last vestige of his power to legitimate a management by a vote is in the hands of the pension trustees. He has an expectation arising out of the fact that he may have performed a certain number of years of acceptable work and fulfilled a certain number of other conditions. But does he have any property right in the pension trust? The courts say no. The power-what is left of it - lies in the trustees, or in those insurance companies which administer trusts.

FREE SOCIETY, supra note 87, at 11-12; see also Frank Partnoy, Berle and Corporation Finance: Everything Old Is New Again, 42 SEATTLE U. L. ReV. 499 (2019) (also noting that Berle foresaw this 
These efforts are similar in character to other initiatives that hold the promise for later, more universal convergence of principles relevant to a global New Deal. The willingness of strategically vital and economically powerful states like California to embrace efforts to address climate change, ${ }^{148}$ and to embrace stronger protections for workers, ${ }^{149}$ can weaken the negative effects of national nativism and provide a sound basis for future national and international action. ${ }^{150}$ Within corporate law itself, the

phenomenon). What Berle said of pension funds is relevant to those funds' current analogue - the $401 \mathrm{~K}$ funds in which American forced capitalists must place their funds to invest for retirement.

148. See Barry G. Rabe, Carbon Pricing Durability and the Case of California, BrookINGS INST. (Aug. 30, 2017), https://www.brookings.edu/blog/fixgov/2017/08/30/carbon-pricing-durabilityand-the-case-of-california/ [https://perma.cc/7QWT-EZXA] (describing California's 2012 implementation of a cap-and-trade program and noting that "[s]tate emissions in the sectors the program addresses have continued to decline, although other policies have also played a role. And the California economy has rebounded nicely from recession during this very period. Indeed, who would have thought that California operating cap-and-trade would coincide with unemployment rates that have consistently fallen below those of America's other state super-power: fossil fuel-producing behemoth Texas? It is exactly the opposite of what California Jobs Initiative backers projected in a 2010 ballot proposition battle, when they insisted that cap-and-trade had to be frozen if the state was to be spared devastating job losses and prolonged economic stagnation."); Jeremy Carl \& David Fedor, Tracking Global Carbon Revenues: A Survey of Carbon Taxes Versus Cap-and-Trade in the Real World, 96 ENERGY POL'Y 50, 62-65 (2016) (reporting that California's AB 32 program generates substantial revenue for the state); see also Hiroko Tabuchi \& Henry Fountain, Bucking Trump, These Cities, States and Companies Commit to Paris Accord, N.Y. TIMES (June 1, 2017), https://www. nytimes.com/2017/06/01/climate/american-cities-climate-standards.html [https://perma.cc/SU4SF293] (describing actions of " 30 mayors, three governors, more than 80 university presidents and more than 100 businesses" cooperating to abide by the Paris climate accord that President Trump disavowed).

149. See generally AFL-CIO, Fighting For a BetTER Life: How Working PEOPLE ACross AMERICA ARE ORGANIZING to RAISE WAGES AND IMPROVE WORK 7-8 (2016), https://aflcio.org/ sites/default/files/2017-03/1614_WageSummitReport.pdf [https://perma.cc/T3AB-6JPW] (summarizing state-level efforts to secure legislation establishing a minimum wage, improving paid sick day policies, requiring equal pay, requiring "more human-friendly" work schedules, and increasing pay for tipped workers).

150. Rob Jordan, Stanford Experts Weigh in on the Impact and Influence of California's Ambitious Global Warming Legislation, STAN. NEWS (Sept. 1, 2016), https://news.stanford.edu/ 2016/09/01/impact-influence-californias-global-warming-legislation/ [https://perma.cc/GAR8-2FF2] ("California's leadership on addressing climate change has played a strong role in building recognition for the importance of actors other than national governments and for structuring the Paris Agreement as a way to embrace collaborations among nations, states, communities and companies") (quoting Chris Field, the Melvin and Joan Lane Professor for Interdisciplinary Environmental Studies and professor in the School of Earth, Energy \& Environmental Sciences at Stanford); Coral Davenport \& Adam Nagourney, Fighting Trump on Climate, California Becomes a Global Force, N.Y. TIMES (May 23, 2017), https://www.nytimes.com/2017/05/23/us/california-engages-world-and-fights-washington -on-climate-change.html [https://perma.cc/D565-WBED] (“As President Trump moves to reverse the Obama administration's policies on climate change, California is emerging as the nation's de facto negotiator with the world on the environment. The state is pushing back on everything from White House efforts to roll back pollution rules on tailpipes and smokestacks, to plans to withdraw or weaken the United States' commitments under the Paris climate change accord."); see Moshe Z. Marvit, The Way Forward for Labor is through the States, AM. PROSPECT (Sept. 1, 2017), http://prospect.org/ article/way-forward-labor-through-states [https://perma.cc/2SHB-48NR] ("In most... areas of 
emergence of a form of corporation that puts some real, if tempered, binding legal and market force behind principles of social responsibility, the Benefit Corporation, can temper short-termism and externality risk in a useful way. ${ }^{151}$ This is if it is embraced by the center-of-the-plate investors now espousing ESG and other buzzwords for doing things the right way. ${ }^{152}$ The Benefit Corporation model also has international utility, as its principles are analogous to those embraced by many EU and OECD company laws, ${ }^{153}$ and could provide a basis for convergence around a model that does not just give lip service to social responsibility, but gives it market and legal strength. ${ }^{154}$

\section{VI.}

In terms of paying for a muscular, international global New Deal, we know that Berle was not shy in his lifetime in supporting efforts to make the privileged pay their fair share, and we also know that his understanding

worker protection - from minimum wage to antidiscrimination laws - the federal government has set the floor under which states and cities may not go, but they can and often do raise the ceiling by increasing state or local minimum wage or including additional protected categories such as sexual orientation to existing protections. Indeed, the evolution of many of the nation's employment and civil rights protections began at the state level and trickled up to the federal government.").

151. See generally Leo E. Strine, Jr., Making It Easier for Directors to "Do the Right Thing"?, 4 HARV. BUS. L. REV. 235 (2014).

152. DEL. CODE ANN. tit. 8, §362(a) (2018) (“A 'public benefit corporation' is a for-profit corporation ... that is intended to produce a public benefit ... and to operate in a responsible and sustainable manner."); Strine, Jr., Making It Easier for Directors to "Do the Right Thing"? supra note 151; Memorandum from Martin Lipton 1 (May 2, 2018) (on file with author) (“[I]t is recognized that ESG [environmental, social and governance], CSR [corporate social responsibility] and PRI [the UN's principles for responsible investment] are essential factors in sustainable long-term investment to create growing shareholder value. If the purpose of a corporation does not include ESG, CSR and PRI, it is unlikely that it will be able to create the sustainable long-term growth being sought by the people for whom the investors are acting.").

153. See Index of Codes, EUR. CORP. GOvernANCE INST., http://www.ecgi.org/codes/all codes.php (last visited Dec. 28, 2018) (collecting codes of various EU member states); HOLLY J. Gregory \& Robert T. SimmelkJaer, II, WeIL, Gotshal \& MANGES LlP, Discussion of INDIVIDUAL CORPORATE GOVERNANCE CODES RELEVANT TO THE EUROPEAN UNION AND ITS MemBer STATES, ANNEX IV (2002) http://ec.europa.eu/internal_market/company/docs/corpgov/ corp-gov-codes-rpt-part2_en.pdf (reviewing corporate governance codes of EU member states that show that often the managers are required to act in the best interests of the company, taking into consideration the interests of the shareholders, the employees, and sometimes even the general public).

154. The Benefit Corporation model institutionalizes the social responsibilities that Berle already envisioned corporations to have. Adolf A. Berle, Jr., "Control” in Corporate Law, 58 Colum. L. REV. 1212, 1215 (1958) ("[O]ur conception of [corporate] control . . . is no longer solely an attribute of stock ownership, though stock ownership plays a part. It is no longer merely a definable portion of the bundle of rights held by stockholders, whether separable or inseparable from the stock itself. It is not a 'thing' but a function. It is essentially a variety of political process - non-statist and therefore, in our vocabulary, 'private,' but with substantial public responsibilities. The holder of control is not so much the owner of a proprietary right as the occupier of a power-position."); see also Adolf A. Berle, Jr., Modern Functions of the Corporate System, 62 CoLuM. L. REv. 433, 446 (1962) ("When I buy AT\&T or General Motors, I do not remotely 'invest in' either concern.”). 
of economics was sharp. ${ }^{155}$ Berle believed that large corporations and their controllers had generated wealth in large measure because of help from government, and owed a corresponding duty of social responsibility. ${ }^{156}$ Therefore, it would not be lost on him that simply by asking for the huge winners over the last quarter century to pay more sizable taxes, needed revenues could be found that would fund required investments and stabilize guarantees critical to economic security. ${ }^{157}$ By adopting Pigouvian taxes on carbon and securities trades, ${ }^{158}$ huge amounts of

155. Welfare of the Masses, supra note 7, at 469.

156. Berle anticipated today's concerns about corporations hoarding unused capital abroad and expending resources on stock-buybacks, rather than new investments in production growth. See, e.g., Emily Stewart, Corporate Stock Buybacks Are Booming Thanks to the Republican Tax Cuts, Vox (Mar. 22, 2018), https://www.vox.com/policy-and-politics/2018/3/22/17144870/stock-buybacks-repu blican-tax-cuts [https://perma.cc/MFJ9-M2SR] (arguing that stock-buybacks "result in corporations giving billions of dollars to their shareholders instead of investing in something more productive and broadly beneficial to the economy"); Jim Tankersley, Tax Havens Blunt Impact of Corporate Tax Cut, Economists Say, N.Y. TIMES (June 10, 2018), https://www.nytimes.com/2018/06/10/business/ corporate-tax-cut.html [https://perma.cc/APM8-8SJT] (arguing that "multinational corporations based in the United States and other advanced economies have sheltered nearly 40 percent of their profits in tax havens like Bermuda, depriving their domestic governments of tax revenues and enriching wealthy shareholders"). Berle believed that corporations had a duty to engage in research and development to advance technological progress and create the industries of the future. A New Look at Management Responsibility, supra note 139, at 4 ("A well-run corporation ought not to have to start looking around for something to do. Presumably it has a research and development department whose precise business is to discover new needs, or better ways of satisfying old needs, or development of new and useful products, or better ways of producing old ones."). Berle also believed corporations had a duty to put corporate capital to work to create community and job growth. $I d$. (noting that the tax law favoring corporate rapid depreciation of assets was "offered on the assumption that the corporations benefitting from it - that is, accumulating more capital than before-will promptly put that capital to work and thereby support an increase in the productivity, the employment, and the general economic health of the country. The hoped for effect is that total product will be increased, that men otherwise unemployed will be kept at work and put to work, that greater and newer product development will occur-because managements do put this capital to work.").

157. E.g., BERLE \& MEANS, supra note 68, at 356 ("Neither the claims of ownership [i.e., stockholders'] nor those of control [i.e., corporate managers'] can stand against the paramount interests of the community."); see also Adolf A. Berle, Jr., For Whom Corporate Managers Are Trustees: A Note, 45 HARV. L. REV. 1365, 1372 (1932) ("Most students of corporation finance dream of a time when corporate administration will be held to a high degree of required responsibility - a responsibility conceived not merely in terms of stockholders' rights, but in terms of economic government satisfying the respective needs of investors, workers, customers, and the aggregated community. Indications, indeed, are not wanting that without such readjustment the corporate system will involve itself in successive cataclysms perhaps leading to its ultimate downfall."). See generally Henry J. Aaron, Can Taxing the Rich Reduce Inequality? You Bet It Can!, BrookIngs Inst. (Oct. 2015), https://www.brookings.edu/wp-content/uploads/2016/06/taxing-the-rich-you-bet-aaron.pdf [https://perma.cc/J7R9-397R] (finding that a standalone increase in the top tax bracket "would meaningfully increase the degree to which the tax system reduces economic inequality ... even though it would fall on just $1 / 2$ of 1 percent of all taxpayers and barely half of their income").

158. See N. Gregory Mankiw, A Carbon Tax That America Could Live With, N.Y. Times (Aug. 31, 2013), https://www.nytimes.com/2013/09/01/business/a-carbon-tax-that-america-could-live-with. html?_r=0 [https://perma.cc/SF3P-ZJMX] (explaining that a carbon tax, which "would induce people to "internalize the externality" by "charg[ing] a fee for each emission of carbon" that is "built into the 
revenue could be generated while helping to reduce carbon use through market forces and decreasing the possibility of another financial crisis by reducing the incentives for trades without economic investment value and the churning of portfolios in reaction to momentary trends. ${ }^{159}$ Last but not least, if the U.S., the EU, and the larger OECD community stamp out tax havens and inversion arbitrage, ${ }^{160}$ the ability of large corporations to continue to shift more and more of the costs of running societies from the privileged to the many can be weakened and even reversed. ${ }^{161}$

prices of products and lifestyles" is, "[a]mong economists ... largely a no-brainer," pointing to a December 2011 survey of 41 economists, 91 percent of whom agreed with the statement that " " [a] tax on the carbon content of fuels would be a less expensive way to reduce carbon-dioxide emissions than would a collection of policies such as 'corporate average fuel economy' requirements for automobiles”); William Gale, The Wisdom of a CARbON TAX: SurPrisingly, a CARbon TAX COUld APPEAl to Both LiBerals AND CONSERVATIVES 3 (2017), http://firstyear2017.org/essay/ the-wisdom-of-a-carbon-tax [https://perma.cc/64AP-BB35] ("Carbon taxes would contribute to a cleaner, healthier environment and better environmental and energy policy by providing price signals to those who pollute. Not surprisingly, most analyses find that a carbon tax could indeed significantly reduce emissions. Gilbert Metcalf of Tufts University estimates that a $\$ 15$ per ton tax on CO2 emissions that rises over time would reduce greenhouse gas emissions by 14 percent, while Jenny Sumner, Lori Bird, and Hillary Smith of the National Renewable Energy Laboratory estimate that the European countries' carbon taxes have had a significant effect on emissions reductions, attributing reductions of up to 15 percent to a carbon tax. Furthermore, the University of Ottawa found that the carbon tax implemented in British Columbia led to a 10 percent reduction in greenhouse gas emissions in the province, compared to less than 5 percent for the rest of Canada, where comprehensive carbon taxes were not applied."); LeONARD E. BURMAN ET AL., TAX POL'y CTR., FinANCIAL TRANSACTION TAXES: AN OVERVIEW 7 (Jan. 2016), https://www.taxpolicycenter.org/publications/financialtransactions-taxes/full [https://perma.cc/QH88-8JVN ] (finding that a tax on securities transactions "could raise a maximum of about 0.4 percent of GDP ( $\$ 75$ billion in 2017) currently in the United States ... allowing for reasonable behavioral responses in trading, maximum revenue would occur if the base rate were about 0.34 percent").

159. THE ASPEN INST., supra note 127, at 19 (summarizing studies indicating that a growing global middle class - and associated higher incomes and consumption levels-will raise carbon emissions, but that the income effect on carbon emissions may be mitigated by, among other things, urbanization, because "rural households tend to have a higher carbon footprint than urban households" due to carbon intensive transport).

160. The urgency of this task may have been fueled by the massive tax cut package passed by Congress last year, as it provides more incentives to offshore not just assets, but also jobs. Reuven S. Avi-Yonah, The Tax Act Actually Promotes Offshore Tricks, Am. ProsPect (June 28, 2018), https://www.prospect.org/article/tax-act-actually-promotes-shore-tax-tricks [https://perma.cc/H8MW -ZVMQ]. More generally, that law will cut taxes for corporations and the wealthy enormously, put long term upward pressure on middle class tax bills, and create huge deficit spending that has already led to calls for cuts in core New Deal/Great Society programs that reduce poverty, economic insecurity, and inequality. Heather Boushey \& Greg Leiserson, Worsening Inequality, AM. PROSPECT (June 28, 2018), https://www.prospect.org/article/worsening-inequality [https://perma.cc/DE47FUYA]; Matt Gardner, The Two Biggest Lies in Donald Trump's Tax Plan, AM. ProsPeCt (June 28, 2018), https://www.prospect.org/article/two-biggest-lies-donald-trumps-tax-plan [https://perma.cc/ K29X-8EFM].

161. See generally OXFAM AM., BROKEN AT THE TOP: HOW AMERICA's DYSFUNCTIONAL TAX SYSTEM COSTS BILlIONS IN CORPORATE TAX DODGING 1 (2016), https://www.oxfamamerica.org/ static/media/files/Broken_at_the_Top_4.14.2016.pdf [https://perma.cc/Q2JM-DTH9] (reporting that "[t]ax dodging by multinational corporations costs the US approximately $\$ 111$ billion each year," and 
For all these reasons, therefore, it is likely that Berle would view a global New Deal as a viable and compulsory objective. But what he would find most worrying is the lack of voices willing to speak hard truths in a non-paternalistic way. To tell workers that their futures do not rest in dirty coal mines but in new jobs that are safer and more fulfilling. That the way to conquer our fears is to marshal our huge resources and talents, and to work together to create a nation and world where the promise of a better life is made real for all our brothers and sisters. Where are the leaders with the guts and conscience to be honest? To admit that we cannot turn inward to solve our problems? To insist that we instead must boldly engage with the world, to make even stronger than the forces of capital the institutions that guarantee to people the rights essential to their economic security?

With the planet's inhabitants now numbered in the billions, and the scope of their impact on each other more substantial, the ability that we have to recover from dawdling or, even worse, reversals in progress, is diminishing. To read Berle is to recognize how complacent and defeatist we have become. His writings reflect the confidence of earlier eras that despite two world wars, genocides, depressions, and other catastrophes, the world was moving toward a better period for all, where the liberties and rights fundamental to human happiness would be enjoyed by many more of the world's citizens. Berle's writings are free of the timorousness and small ball that characterize our national discussion of the right way forward. Berle revered FDR in no small part because of FDR's willingness to act to provide genuine hope based on the reality of genuine progress. ${ }^{162}$ To the extent he faulted FDR, it was for not being too bold in pushing the New Deal. ${ }^{163}$

that the "same tactics corporations use to dodge US tax sap an estimated \$100 billion every year from poor countries, preventing crucial investments in education, healthcare, infrastructure, and other forms of poverty reduction."); KIMBERLy ClaUSING, TAX POL'Y CTR., CORPORATE INVERSIONS 6 (2014), https://www.taxpolicycenter.org/publications/corporate-inversions/full [https://perma.cc/YN7UALCL] (reporting that a Joint Committee on Taxation estimated that a proposal limiting inversions would raise $\$ 19$ billion over 10 years); Renu Zaretsky, Baskets of Billions, Inversions and Revenues, TAXVOX (July 22, 2014), https://www.taxpolicycenter.org/taxvox/baskets-billions-inversions-andrevenues [https://perma.cc/9UV4-PWKZ] ("Jobs might not necessarily go overseas when a corporation completes an inversion, but a state's tax base will shrink when a state's formula to calculate its corporate income tax relies on the corporation's total federal income. In the absence of corporate inversions, states would have received $\$ 73.1$ billion in corporate income tax revenue between 2008 and 2012, according to the Citizens for Tax Justice.").

162. Reshaping the American Economy, supra note 6, at 221 ("Franklin Delano Roosevelt has many monuments in many fields. The result of his redirection of the federal state is not the least. Nor is it the least expressive of the man himself: of his sympathy and his awareness; of his gay, even ironic, appreciation of the defects as well as the merits of the American political system; of his inveterate optimism (modified by kindly skepticism) as to human possibilities; of his unconquerable belief that America could make of herself whatever she really wished to be.").

163. Id. at 218 . 
At a time when our scientific and productive capacities are immense, we have no legitimate excuse for being defeatist. With far less sacrifice than was asked of prior generations, we can reduce economic insecurity for working people in our nation, and help universalize the values we most treasure. But that won't happen unless the realism Berle exemplified is combined with his optimism and commitment to a capitalism that works for all. When fear is rational, it does not go away by ignoring it. It goes away when the sources of the fear are addressed with skill and confidence. Berle's recognition of that could not be more relevant to the current moment. 